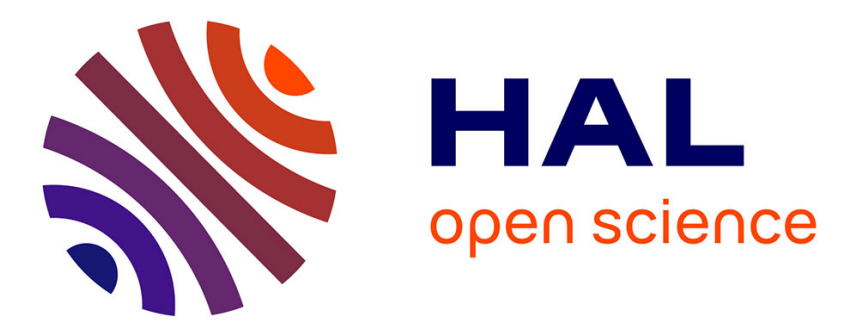

\title{
Spatial and temporal variation of tritium concentrations during a dam flushing operation
}

Lepage Hugo, Frédérique Eyrolle, Loic Ducros, David Claval

\section{To cite this version:}

Lepage Hugo, Frédérique Eyrolle, Loic Ducros, David Claval. Spatial and temporal variation of tritium concentrations during a dam flushing operation. Journal of Environmental Radioactivity, 2020, 218, pp.106261. 10.1016/j.jenvrad.2020.106261 . hal-02531823

\section{HAL Id: hal-02531823 \\ https://hal.science/hal-02531823}

Submitted on 7 Jul 2020

HAL is a multi-disciplinary open access archive for the deposit and dissemination of scientific research documents, whether they are published or not. The documents may come from teaching and research institutions in France or abroad, or from public or private research centers.
L'archive ouverte pluridisciplinaire HAL, est destinée au dépôt et à la diffusion de documents scientifiques de niveau recherche, publiés ou non, émanant des établissements d'enseignement et de recherche français ou étrangers, des laboratoires publics ou privés.

\section{(1) (1) $\$$}

Distributed under a Creative Commons Attribution - NonCommercial - NoDerivatives 44.0 


\section{Manuscript Details}

\section{Manuscript number}

Title
JENVRAD_2020_65_R1

Spatial and temporal variation of tritium concentrations during a dam flushing operation

Research Paper

\section{Article type}

Abstract

Tritium is a radionuclide commonly observed worldwide in riverine systems. In the Rhône River downstream the Lake Geneva (Switzerland and France), its occurrence is also related to its use for its luminescent properties in watchmaking paints. In fact, tritium is regularly observed at anomalous levels in this river and extreme events such as flushing operations might conduct to its transport downstream. In the Rhône River, characterized by 21 dams downstream the Geneva Lake, such operations are regularly organized to remove the sediments and limit problematic consequences such as siltation and increased flooding hazards. The consequences of dam flushing operations on tritium concentrations were thus investigated. Samples of Suspended Particulate Matter (SPM) and water were collected in the Rhone River downstream of Geneva in June 2012, during a planned flushing operation of three upstream reservoirs (Verbois, Chancy-Pougny and Génissiat). The concentrations of tritiated water (HTO) and organically bound Tritium (OBT) were measured and compared to reference concentrations. The flushing operations had no impact on the HTO concentration while the increases observed were related to the authorized releases of HTO from a nuclear power plant located downstream the dams. High increases of OBT concentrations in SPM were observed at two stations (Creys-Malville and Jons) without clear spatial or temporal trends. These anomalous peaks could be explained by the heterogeneous spatial distribution of technogenic tritium leading to large variations of tritium concentrations within the samples even though collected in areas close to each other. The results highlight the need to investigate the amount of such technogenic tritium currently stored in the upstream Rhone River as it might be significant.

\section{Keywords}

\section{Taxonomy}

Corresponding Author

Corresponding Author's Institution

\section{Order of Authors}

Suggested reviewers

Opposed reviewers
Radionuclide; Technogenic tritium; organically bound Tritium; sediment; suspended particulate matter; watchmaking paint

River Basin Management, Environmental Science, Environmental Radioactivity

Hugo LEPAGE

IRSN

Hugo LEPAGE, Frédérique Eyrolle, Loïc Ducros, David CLAVAL

Shinji Ueda, C. Le Gal La Salle, Sang Bog Kim

Philippe pjb@lsce.ipsl.fr 


\section{Submission Files Included in this PDF}

\section{File Name [File Type]}

Response to Reviewers .docx [Response to Reviewers (without Author Details)]

Manuscript_Revised_with_marks.docx [Revised Manuscript with Changes Marked (without Author Details)]

Highlights.docx [Highlights]

Abstract_revised.docx [Abstract]

Graphical Abstract_revised.pdf [Graphical Abstract]

Title page.docx [Title Page (with Author Details)]

Manuscript_Revised.docx [Manuscript (without Author Details)]

Figure captions_revised.docx [Figure]

Figure 1.pdf [Figure]

Figure 2_revised.pdf [Figure]

Figure 3_revised.pdf [Figure]

Table.docx [Table]

declaration-of-competing-interests.docx [Conflict of Interest]

ESM_revised.docx [e-Component]

To view all the submission files, including those not included in the PDF, click on the manuscript title on your EVISE Homepage, then click 'Download zip file'. 


\begin{tabular}{|c|c|c|}
\hline Comments from reviewer & Answers from corresponding author & Correction in the manuscript \\
\hline Reviewer 1 & $\begin{array}{l}\text { Explanation for the use of SPM and sediment in } \\
\text { the manuscript: } \\
\text { - SPM is used to characterize the particles } \\
\text { that are transported by the river. It is what } \\
\text { we sampled to measure the OBT. } \\
\text { - Sediment characterized the particles } \\
\text { stored either in the studied dams or along } \\
\text { the river. } \\
\text { Sediment could be resuspended (for example } \\
\text { during the flushing operations) and thereafter } \\
\text { considered as SPM as well as SPM could be stored } \\
\text { by sedimentation and considered as sediment. } \\
\text { Since the reviewers } 2 \text { and } 3 \text { did not complain on } \\
\text { that point, we did not changed the terminology of } \\
\text { SPM and sediments. }\end{array}$ & \\
\hline Line 12: Insert (SPM) & Added & $\begin{array}{l}\text { Samples of Suspended Particulate Matter (SPM) } \\
\text { and water were collected in the Rhone River } \\
\text { downstream of Geneva in June } 2012[\ldots]\end{array}$ \\
\hline $\begin{array}{l}\text { - Line 18: High increase of OBT } \\
\text { concentration from SPM or sediment? I am } \\
\text { confused between sediment and SPM through } \\
\text { whole manuscript. Is SPM a part of sediment? }\end{array}$ & $\begin{array}{l}\text { See first comment for SPM and sediment } \\
\text { definition. } \\
\text { Although the increase was observed in the SPM } \\
\text { sampled at two of the four stations, it was directly } \\
\text { related to the resuspension during the flushing } \\
\text { operations of the sediments stored in the dams or } \\
\text { in the river. }\end{array}$ & $\begin{array}{l}\text { High increases of OBT concentrations in SPM were } \\
\text { observed at two stations (Creys-Malville and Jons) } \\
\text { without clear spatial or temporal trends. }\end{array}$ \\
\hline
\end{tabular}




\begin{tabular}{|c|c|c|}
\hline $\begin{array}{l}\text { - Line 36: "the nuclear sector is allowed to } \\
\text { release low-activity liquid effluent into rivers". Is } \\
\text { it including SPM or OBT? If yes, insert a } \\
\text { reference. }\end{array}$ & $\begin{array}{l}\text { Nuclear industries release radionuclides as } \\
\text { dissolved species only. No particles are released. } \\
\text { However, dissolved species can fix to suspended } \\
\text { solid particles transported by the river. Tritium is } \\
\text { transferred in the environment predominantly as } \\
\text { dissolved free HTO and is known to be a } \\
\text { conservative radionuclide during water mass } \\
\text { transfer and mixing. Part of tritium can associate } \\
\text { to particulate organic matter during } \\
\text { photosynthesis (OBT). }\end{array}$ & \\
\hline - $\quad$ Line 40: These forms? & OBT - corrected in the text & $\begin{array}{l}\text { Part of OBT do not easily exchange with the } \\
\text { surrounding water molecules and persist in the } \\
\text { environment until organic compounds are } \\
\text { biodegraded. }\end{array}$ \\
\hline $\begin{array}{l}\text { Line } 56: 0.6 \times 10^{9} \text {. Is it suspended or } \\
\text { precipitated in the bottom? }\end{array}$ & $\begin{array}{l}\text { It is particles that were suspended but got stored } \\
\text { by sedimentation. }\end{array}$ & \\
\hline $\begin{array}{l}\text { - Line 61-62: What is a difference between } \\
\text { contaminated sediments and SPM? }\end{array}$ & $\begin{array}{l}\text { See first comment for SPM and sediment } \\
\text { definition. } \\
\text { Sediments stored in the dam might be either } \\
\text { contaminated or depleted so as the SPM. }\end{array}$ & \\
\hline Line 71: soil washout by rain? & Soil erosion. Corrected & $\begin{array}{l}\text { [...] or finally progressively transferred due to soil } \\
\text { erosion (Schürch et al., 2003). }\end{array}$ \\
\hline $\begin{array}{l}\text { Line } 99-110 \text { : Format error? All stations } \\
\text { (A,B,C,D) have different sampling periods from } 6 \\
\text { days to } 30 \text { days. Do you have any specific reason? }\end{array}$ & $\begin{array}{l}\text { Unfortunately, due to logistic constraint, periods } \\
\text { of sampling differed depending on the stations. } \\
\text { Sampling at station A and B needed specific } \\
\text { authorization due to safety rules during the } \\
\text { flushing operations and sampling were only } \\
\text { authorized during the flushing of the closest dams. } \\
\text { Detail added to the manuscript. }\end{array}$ & $\begin{array}{l}\text { To characterize the impact of the dam flushing } \\
\text { operations on the concentrations of HTO (water } \\
\text { samples) and OBT (SPM samples), samples were } \\
\text { collected at four stations (Figure 1, Table 1) with } \\
\text { different sampling periods due to logistic } \\
\text { constrain }\end{array}$ \\
\hline
\end{tabular}




\begin{tabular}{|c|c|c|}
\hline $\begin{array}{l}\text { Line 118: For SPM sampling, is any water } \\
\text { depth related to? }\end{array}$ & $\begin{array}{l}\text { At Station A B and D, Particle Trap were set in the } \\
\text { bottom of the river while for Station C, the } \\
\text { sampling were conducted approx. } 50 \mathrm{~cm} \text { below the } \\
\text { surface in order to side step potential } \\
\text { heterogeneity of SPM throughout the river cross- } \\
\text { section. } \\
\text { Detail added to the manuscript. }\end{array}$ & $\begin{array}{l}\text { Due to logistic constrain, the PT were set on the } \\
\text { bottom of the river at Stations A, B and D while at } \\
\text { Station C it was approx. } 50 \mathrm{~cm} \text { below the surface. }\end{array}$ \\
\hline - $\quad$ Line 132: detection limit of HTO and OBT? & $\begin{array}{l}\text { With used detection limit and detection threshold } \\
\text { to determine the concentration in our samples as } \\
\text { described in Currie (1968). For both methods, } \\
\text { detection limit was approx. 0.6 Bq. } \mathrm{L}^{-1} \text { with a } \\
\text { detection threshold of approx. } 1.2 \mathrm{~Bq} \cdot \mathrm{L}^{-1} \text {. } \\
\text { Information added in the manuscript. }\end{array}$ & $\begin{array}{l}\text { For both methods, detection limit was approx. } 0.6 \\
\text { Bq. } \mathrm{L}^{-1} \text { with a detection threshold of approx. } 1.2 \\
\text { Bq.L } \mathrm{L}^{-1} \text { (Currie, 1968; Eyrolle et al., 2018). }\end{array}$ \\
\hline $\begin{array}{l}\text { Line 182: How much tritium released } \\
\text { annually from the NPP? }\end{array}$ & $\begin{array}{l}\text { In the Rhône River, almost } 80 \% \text { of HTO come from } \\
\text { the NPP, it is the most released radionuclide in } \\
\text { term of quantity (Eyrolle-Boyer et al., 2015). In } \\
2012 \text {, almost } 210 \text { TBq of HTO were released in the } \\
\text { Rhône River (with } 200 \text { TBq only by NPP). }\end{array}$ & \\
\hline $\begin{array}{l}\text { Line 224: What is the relationship between } \\
\text { sediment and SPM? }\end{array}$ & $\begin{array}{l}\text { Corrected, OBT is heterogeneously distributed in } \\
\text { the sediments. }\end{array}$ & $\begin{array}{l}\text { However, OBT is heterogeneously distributed in } \\
\text { sediments of the Rhône River and large amounts } \\
\text { of this radionuclide are still stored in the Upper } \\
\text { Rhône sediments. }\end{array}$ \\
\hline $\begin{array}{l}\text { Table S1: In C station, MDA is } 1.2 \text { or } 1.5 \text { but } \\
\text { in D station, can be detected up to } 0.6 \mathrm{~Bq} / \mathrm{L} \text {. Are } \\
\text { they use the same technique? }\end{array}$ & $\begin{array}{l}\text { The same technique was used, it depended not } \\
\text { only on the detection limit but also on the } \\
\text { detection threshold. See information on detection } \\
\text { limit in the comment above. }\end{array}$ & \\
\hline Reviewer 2 & & \\
\hline
\end{tabular}




\begin{tabular}{|c|c|c|}
\hline $\begin{array}{l}\text { 1. In order to determine how turbid in the river } \\
\text { water collected in this study, please indicate and } \\
\text { explain the SPM amount ( } \mathrm{mg} / \mathrm{L} \text { ) of the river water. }\end{array}$ & $\begin{array}{l}\text { The discharge of the river and its SPM } \\
\text { concentration were investigated in a thesis in } \\
\text { French (Launay, 2014), while the data are } \\
\text { available online (Thollet et al,. 2018). A specific } \\
\text { focus on Jons was conducted in Lepage et al. } \\
\text { (2020). } \\
\text { These references and additional information were } \\
\text { added in the manuscript and in the electronic } \\
\text { supplementary materials. }\end{array}$ & $\begin{array}{l}\text { Discharge varied from } 129 \mathrm{~m}^{3} \mathrm{~s}^{-1} \text { to } 631 \mathrm{~m}^{3} \mathrm{~s}^{-1} \text { in } \\
\text { the vicinity of Chancy-Pougny during the flushing } \\
\text { periods (Figure ESM1 in electronic supplementary } \\
\text { materials). Discharge increased from upstream to } \\
\text { downstream and reached maximal values ( } 1600 \\
\mathrm{~m}^{3} \mathrm{~s}^{-1} \text { ) at Jons (Station D in Figure 1) on the } 06 / 14 \text {, } \\
w^{2} \text { ich correspond to discharges observed for } \\
\text { biennial flood (Lepage et al., 2020). SPM } \\
\text { concentration reached } 16.6 \mathrm{~g} \mathrm{~L}^{-1} \text { near Génissiat } \\
\text { during its flushing and the highest SPM } \\
\text { concentration was observed during the flushing of } \\
\text { Verbois and Chancy-Pougny with } 48.6 \mathrm{~g} \mathrm{~L}^{-1} \\
\text { observed at Chancy-Pougny (Figure ESM1 in } \\
\text { electronic supplementary materials). The SPM } \\
\text { concentrations decreased with distance and the } \\
\text { maximum concentrations observed at Jons was } \\
0.9 \mathrm{~g} \mathrm{~L}^{-1} \text {. It has to be noted that floods occurred in } \\
\text { two tributaries (Ain and Fier - Figure 1) with a } \\
\text { limited impact on the transport of SPM (Launay, } \\
2014 \text {; Lepage et al., 2020). }\end{array}$ \\
\hline $\begin{array}{l}\text { 2. Can you estimate the tritium load into a } \\
\text { downstream using the amount of sediment } \\
\text { released during flushing operations of } 3 \text { dams and } \\
\text { data of OBT concentration in SPM? You should } \\
\text { describe the effect of tritium on the downstream } \\
\text { caused by the dam flushing operation. }\end{array}$ & $\begin{array}{l}\text { Fluxes of SPM related to these flushing operations } \\
\text { were calculated in Lepage et al. (2020) and might } \\
\text { be used to estimate the flux of OBT. However due } \\
\text { to its heterogeneous distribution in the SPM it is } \\
\text { difficult to evaluate an accurate load of OBT } \\
\text { exported. }\end{array}$ & \\
\hline $\begin{array}{l}\text { 3. Please add information such as organic matter } \\
\text { quantity (TOC, TN, etc.) to clarify the composition } \\
\text { in SPM. }\end{array}$ & $\begin{array}{l}\text { The particulate organic carbon and grain size } \\
\text { distribution were added in the Table S2 and in the } \\
\text { manuscript (in Mat \& Met., Results and } \\
\text { Discussion) }\end{array}$ & \\
\hline
\end{tabular}




\begin{tabular}{|c|c|c|}
\hline $\begin{array}{l}\text { 4. By the way, are there an impact of high- } \\
\text { concentration tritium SPM on ecosystems? Is } \\
\text { there bioaccumulation through the food chain by } \\
\text { SPM? If so, please describe in the "introduction", } \\
\text { "discussion" or "conclusion". }\end{array}$ & $\begin{array}{l}\text { To our knowledge, any investigation was } \\
\text { conducted on the radiotoxicity of the technogenic } \\
\text { tritium observed in the Rhône River. } \\
\text { Additional information was added to the } \\
\text { manuscript. }\end{array}$ & $\begin{array}{l}\text { The radiotoxicity of free tritium (HTO) or } \\
\text { organically bound tritium to naturally occurring } \\
\text { organic compounds (OBT) are low comparing to } \\
\text { most other natural or artificial radionuclides. } \\
\text { Nevertheless, the specific radiotoxicity of } \\
\text { organically bound tritium to synthetic organic } \\
\text { particles are unknown to our knowledge as well as } \\
\text { their transfer rates toward living organisms. }\end{array}$ \\
\hline $\begin{array}{l}\text { 5. Precipitation information is needed to } \\
\text { distinguish the effects of dam flushing and } \\
\text { precipitation. Provide information about } \\
\text { precipitation during the observation period and } \\
\text { please write that the SPM in the river water is not } \\
\text { affected by precipitation. }\end{array}$ & $\begin{array}{l}\text { During the flushing operations, floods occurred in } \\
\text { two upstream tributaries (Ain and Fier rivers), } \\
\text { downstream Stations A and B (Figure 1). Their } \\
\text { impacts remained low as the input of SPM by } \\
\text { these tributaries was strongly lower than the flux } \\
\text { from the flushing operations (Launay. 2014; } \\
\text { Lepage et al., 2020). }\end{array}$ & $\begin{array}{l}\text { It has to be noted that floods occurred in two } \\
\text { tributaries (Ain and Fier - Figure 1) with a limited } \\
\text { impact on the transport of SPM (Launay, 2014; } \\
\text { Lepage et al., 2020). }\end{array}$ \\
\hline $\begin{array}{l}\text { 1. Change from unit of "Bq.L-1" to "Bq L-1" in } \\
\text { manuscript. No period required. }\end{array}$ & Corrected for the whole manuscript. & \\
\hline $\begin{array}{l}\text { 2. Line 45: Change from "coastal rivers" to } \\
\text { "mountainous rivers". }\end{array}$ & Corrected & $\begin{array}{l}\text { [...] HTO concentrations in two small mountainous } \\
\text { rivers were shown to be higher during flood } \\
\text { events than in baseflow conditions (Ueda et al., } \\
\text { 2015) [...] }\end{array}$ \\
\hline $\begin{array}{l}\text { 3. It is easier to understand if you insert tritium } \\
\text { concentration ranges in the river water and } \\
\text { sediments of the Rhone River in Figures } 2 \text { and } 3 . \\
\text { For example, see Fig. } 3 \text { of Science of the Total } \\
\text { Environment Eyrolle et al (2018) Vol 643, pp } 40-51 .\end{array}$ & $\begin{array}{l}\text { Ranges of HTO and OBT concentrations were } \\
\text { added to the figures } 2 \text { and } 3 \text {. }\end{array}$ & \\
\hline \multicolumn{3}{|l|}{ Reviewer 3} \\
\hline $\begin{array}{l}\text { - The graphical abstract looks inconsistent with } \\
\text { the findings. Heterogeneous distribution of OBT } \\
\text { is the key finding in my understanding. If so, the }\end{array}$ & Graphical abstract was improved & \\
\hline
\end{tabular}




\begin{tabular}{|c|c|c|}
\hline $\begin{array}{l}\text { heterogeneity should be illustrated in the } \\
\text { graphical abstract. }\end{array}$ & & \\
\hline $\begin{array}{l}\text { - More information is needed for heterogeneity } \\
\text { for OBT. I remember that the author(s) don't } \\
\text { have the data for the bed sediment, but how } \\
\text { about the concentration of SPM (kg/L) in river } \\
\text { water? That information helps the division of } \\
\text { heterogeneity of SPM concentration and } \\
\text { heterogeneity of OBT concentration (probably } \\
\text { the unit should be Bq/kg instead of Bq/L in this } \\
\text { case). I'm not familiar with the Rhone river but } \\
\text { imagine heterogeneity of SPM concentration is } \\
\text { large during such dam flushing operations. }\end{array}$ & $\begin{array}{l}\text { Variation of discharge and SPM concentration } \\
\text { were added in the electronic supplementary } \\
\text { materials and in the manuscript. However, it is } \\
\text { difficult to link the OBT to the SPM as the samples } \\
\text { were collected during several hours in order to get } \\
\text { a sufficient amount of SPM to realize the analysis. } \\
\text { The Bq L } \mathrm{L}^{-1} \text { of combustive water as described in our } \\
\text { paper directly express the content of tritium } \\
\text { associated with organic compounds. Bq } \mathrm{kg}^{-1} \mathrm{can} \\
\text { conduct to erroneous interpretation of OBT } \\
\text { results because it doesn't consider organic matter } \\
\text { content in suspended or deposited sediment } \\
\text { samples. However, results in Bq } \mathrm{kg}^{-1} \text { were added } \\
\text { in the ESM in the Table ESM2 }\end{array}$ & $\begin{array}{l}\text { This result highlights that these tritiated particles } \\
\text { most probably come from the sediment stored in } \\
\text { the dams and flushed during the operations. It } \\
\text { also confirms their heterogeneously distribution } \\
\text { as such increase of OBT concentration was not } \\
\text { observed in Stations A and B. }\end{array}$ \\
\hline
\end{tabular}




\section{Spatial and temporal variation of tritium concentrations during a \\ 2 dam flushing operation}

3 Abstract

4 Tritium is a radionuclide commonly observed worldwide in riverine systems. In the Rhône

5 River downstream the Lake Geneva (Switzerland and France), its occurrence is also related to

6 its use for its luminescent properties in watchmaking paints. In fact, tritium is regularly

7 observed at anomalous levels in this river and extreme events such as flushing operations

8 might conduct to its transport downstream. In the Rhône River, characterized by 21 dams

9 downstream the Geneva Lake, such operations are regularly organized to remove the sediments and limit problematic consequences such as siltation and increased flooding hazards. The consequences of dam flushing operations on tritium concentrations were thus

12 investigated. Samples of Suspended Particulate Matter (SPM) and water were collected in the Rhone River downstream of Geneva in June 2012, during a planned flushing operation of three upstream reservoirs (Verbois, Chancy-Pougny and Génissiat). The concentrations of tritiated water (HTO) and organically bound Tritium (OBT) were measured and compared to reference concentrations. The flushing operations had no impact on the HTO concentration while the increases observed were related to the authorized releases of HTO from a nuclear power plant 18 located downstream the dams. High increases of OBT concentrations in SPM were observed at two stations (Creys-Malville and Jons) without clear spatial or temporal trends. These anomalous peaks could be explained by the heterogeneous spatial distribution of technogenic tritium leading to large variations of tritium concentrations within the samples even though 
of such technogenic tritium currently stored in the upstream Rhone River as it might be significant.

\section{Keywords}

Radionuclide; Technogenic tritium; organically bound Tritium; sediment; suspended particulate matter; watchmaking paint

\section{Introduction}

Tritium $\left({ }^{3} \mathrm{H}\right.$ - half-life $=12.3$ years $)$ is a radionuclide commonly observed for several decades in the environment (Eisenbud et al., 1979). In rivers, ${ }^{3} \mathrm{H}$ can be liquid (tritiated water - HTO) or incorporated in particulate organic compounds (Organically Bound Tritium - OBT) (Kim et al., 2013). The HTO is the predominant form of tritium in the environment and it closely follows the water cycle (Ciffroy et al., 2006; Eyrolle-Boyer et al., 2015). It is commonly used as a tracer in hydrogeology and marine studies (Ducros et al., 2018). The HTO is also the most released aqueous radionuclide from nuclear facilities, with levels of activity currently 1000 times higher than the sum of artificial gamma emitters discharged (Eyrolle et al., 2018). In fact, in compliance with the legislation, the nuclear sector is allowed to release low-activity liquid effluent into rivers. The OBT is part of the organic matter cycle and has been measured in sediments and suspended particulate matter (SPM) for decades (Eyrolle et al., 2018). Some of these formsthe OBT do not easily exchange with the surrounding water molecules and persist in the environment until organic compounds are biodegraded. These forms of tritium are expected to be stored in sediments associated with particulate organic matter (Eyrolle-Boyer et al., 2014) and might be affected by extreme events such as flood events or dam flushing operations. In fact, these events strongly affect the behavior of dissolved and particulate contaminants including tritium. For example, after the deposition of tritium following the 
46 Fukushima accident in march 2011, HTO concentrations in two small ceastal-mountainous

47 rivers were shown to be higher during flood events than in baseflow conditions (Ueda et al., 2015) but decreased rapidly the following years to reach background concentration in 2014 . Dams on rivers considerably impact SPM transport, by reducing flow velocity and increasing SPM deposition (Syvitski et al., 2005) and that of their related contaminants (Lepage et al., 2020). Contaminants associated with deposited sediments may also be resuspended and disseminated (Peter et al., 2014) or transferred to the dissolved phase (Bretier et al., 2019; Kalnejais et al., 2010).

In France, the Rhône River is characterized by the presence of 21 hydropower plants and is one of the most nuclearized rivers in the world, with 5 nuclear power plants (NPP) including one in dismantlement, nuclear fuel production, reprocessing plants and research laboratories. From 0.2 to $0.610^{9} \mathrm{~kg}$ of SPM are stored each year along the Rhône River (Bravard and Clémens, 2008), mostly in dam reservoirs (Provansal et al., 2014). Resuspension processes, such as dam flushing operations, are regularly organized to remove stored sediments and limit problematic consequences such as siltation and increased flooding hazards (Brown, 1944; Peteuil et al., 2013). Such dam operations lead either to the resuspension of contaminated sediments stored in the dams, or to the dilution of contaminated SPM by flushing non-contaminated sediments (Lepage et al., 2020).

Moreover, in the past century, most of the OBT was originate from other industrial plants present in the Rhône River and especially in its upstream part that produced luminescent paint used in watches (Eyrolle et al., 2018; Jean-Baptiste et al., 2018). These companies have released fine particles of tritiated compounds (usually tiny tritiated polystyrene spherules a few tens of microns in diameter) used in luminous paints (JeanBaptiste et al., 2007; Krejci and Zeller, 1979; Schürch et al., 2003). In fact, these tritiated 
technogenic particles (hot tritiated particles) could have been released directly into the river by the industrial plants, or transferred into the environment during the waste incineration process, or finally progressively transferred due to soil washouterosion (Schürch et al., 2003). These refractory particles that accumulate in sediments are expected to persist in the environment for a very long time (Eyrolle et al., 2018; Morereau et al., in prep.) and have also been observed in the Mediterranean Sea near the outlet of the Rhône River (Jean-Baptiste et al., 2018). Although a recent review written by Eyrolle et al. (2018) summarized results on its specific behavior in the Rhône River, reports on the impact of hydrological events on OBT concentrations remain rare especially its dynamics during dam flushing operations.

This field study was conducted in the Rhône River downstream the Lake Geneva during the flushing operations of several dams in June 2012. Water and SPM samples were collected at different locations for different periods. The tritium concentrations were characterized and the results were then compared with the contents recorded before the event.

\section{Materials and Method}

\section{Dam location and description of the flushing operations}

This study was conducted along the Upper Rhône River in France and Switzerland, downstream the Lake Geneva (Figure 1). This basin $\left(95,600 \mathrm{~km}^{2}\right.$ at Beaucaire station) constitutes the main SPM input flowing into the Western Mediterranean Sea with a mean SPM

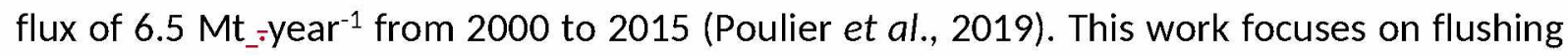
operations conducted in June 2012 in three reservoirs located downstream of Lake Geneva in Switzerland (Figure 1): Verbois, Chancy-Pougny, and Génissiat. These flushing operations are described in Lepage et al. (2020). In brief, the water level of the three dams was lowered following the drawdown flushing method (Fruchard and Camenen, 2012) in order to remove 
stored sediments. The large-volume Génissiat reservoir located downstream of the two other dams was flushed first (4-12 June 2012) in order to compensate for the deposition of the SPM released from the Chancy-Pougny (9-16 June 2012) and Verbois dams (9-22 June 2012). Discharge varied from $129 \mathrm{~m}^{3} \mathrm{~s}^{-1}$ to $631 \mathrm{~m}^{3} \mathrm{~s}^{-1}$ in the vicinity of Chancy-Pougny during the flushing periods (Figure ESM1 in electronic supplementary materials). Discharge increased from upstream to downstream and reached maximal values $\left(1600 \mathrm{~m}^{3} \mathrm{~s}^{-1}\right)$ at Jons (Station D in Figure 1) on the $06 / 14$, which correspond to discharges observed for biennial flood (Lepage et al., 2020). SPM concentration reached $16.6 \mathrm{~g} \mathrm{~L}^{-1}$ near Génissiat during its flushing and the highest SPM concentration was observed during the flushing of Verbois and Chancy-Pougny with $48.6 \mathrm{~g} \mathrm{~L}^{-1}$ observed at Chancy-Pougny (Figure ESM1 in electronic supplementary materials). The SPM concentrations decreased with distance and the maximum concentrations observed at Jons was $0.9 \mathrm{~g} \mathrm{~L}^{-1}$. It has to be noted that floods occurred in two tributaries (Ain and Fier - Figure 1) with a limited impact on the transport of SPM (Launay, 2014; Lepage et al., 2020).

\section{Sampling and samples}

To characterize the impact of the dam flushing operations on the concentrations of HTO (water samples) and OBT (SPM samples), samples were collected at four stations (Figure 1, Table 1) with different sampling periods due to logistic constrain:

- Station A at Pougny, in the downstream vicinity of Chancy-Pougny and Verbois dams. Samples were collected from the $06 / 09 / 2012$ to the $06 / 20 / 2012$ during the flushing operations of these two dams.

- Station B at Seyssel, downstream Génissiat dam and during its flushing operation with samples collected from the 06/04/2012 to the 06/10/2012. 
- Station C at Creys-Malville in a monitoring station used to supply the regulatory control of the releases from NPPs (IRSN, 2015) and used in this study for temporal comparison. Sampling was conducted before, during and after the flushing operations, from the $05 / 25 / 2012$ to the $07 / 01 / 2012$.

- Station D at Jons in a monitoring station (Masson et al., 2018; Thollet et al., 2018) located downstream a NPP (Figure 1) with samples collected for the main period of flushing operations, from the $06 / 04 / 2012$ to the $07 / 03 / 2012$.

Instantaneous water samples were obtained manually using a stainless-steel bucket (approx.

$4 \mathrm{~L}$ ) at stations A, B and D, and by an Automatic Water Sampler (AWS) at station C. The AWS used for water sampling was a Bühler 4011 (HachLange, Germany) and set to collect $10 \mathrm{~mL}$ every 65 minutes to constitute time integrated raw water samples (6 days) stored in glass bottles. Samples were all stored in dark glass bottles at $4^{\circ} \mathrm{C}$ until analyses.

For OBT measurement, SPM samples were collected using Particle Trap (PT). These samplers were built following the German Environmental Specimen Bank model (Masson et al., 2018; Schulze et al., 2007). Water flows through the high-quality stainless steel box and its velocity is reduced by two baffles. SPM settle in two sedimentation basins in the box. Samples were collected every 1 to 4 days (see Table ESMS1 in electronic supplementary materials). Due to logistic constrain, the PT were set on the bottom of the river at Stations A, B and D while at Station C it was approx. $50 \mathrm{~cm}$ below the surface. Prior to analysis, SPM samples were stored in the dark at $4^{\circ} \mathrm{C}$, deep-frozen, freeze-dried, and homogenized through a $2 \mathrm{~mm}$ stainless steel sieve. Dried samples were then immediately sealed under soft vacuum in 
139 aluminized bags until analyses in order to avoid the exchange of water molecules with the 140 atmosphere.

141 Grain-size distribution

$142 \quad$ For the measure of volumetric grain size distribution, a representative aliquot of each 143 wet sample was taken before processing and was analyzed on a CILAS 1190 laser particle size 144 analyzer (Masson et al., 2018) according to the ISO 13320 standard method (AFNOR, 2009). 145 Clay $(<1.95 \mu \mathrm{m})$, Silt $(<63 \mu \mathrm{m})$ and Sand $(<2000 \mu \mathrm{m})$ were estimated.

Particulate Organic Carbon analysis

147 The determination of Particulate Organic Carbon (POC) in SPM samples was performed using a carbon analyzer (Thermo Electron, CHN Flash 2000) by INRA laboratory (Arras, France).

Decarbonation was completed using hydrochloric acid according to the NF ISO 10694 standard method (AFNOR, 1995). The limit of quantification (LQ) was estimated to be $0.05 \mathrm{~g} \mathrm{~kg}^{-1}$ and analytical uncertainty varied between $\sim 3 \%$ and $\sim 6 \% \quad(k=2)$, depending on the POC concentration.

\section{Tritium analyses}

156 The HTO analyses were performed on $20 \mathrm{ml}$ of filtered water $(<0.2 \mu \mathrm{m})$ either directly filtered 157 in the field for punctual samples or in the laboratory for time-integrated ones sampled by 158 AWS. Filtered waters were analyzed by classical scintillation counting for HTO content (Tricarb $1593180 \mathrm{TR} / \mathrm{SL}$ ), by taking an aliquot of $10 \mathrm{~mL}$ and adding $10 \mathrm{~mL}$ of scintillation liquid (UltimaGold 160 LLT). 

sample in a vacuum (10-6 mbar) and storing it for 3 to 4 months (Cossonnet et al., 2009). The

163 Helium-3 is a decay product of tritium-and its concentration is measured by mass spectrometry (Jean-Baptiste et al., 2010). OBT concentrations were converted in Becquerel 165 per liter of combustion water $\left(\mathrm{Bq} \cdot \mathrm{Bq} \mathrm{L}^{-1} \mathrm{cw}\right)$ by using the percentage of hydrogen measured in each sample by a CHNS elemental analyzer (Elementar, vario MICROcube). $1.2 \mathrm{~Bq} \mathrm{~L}^{-1}$ (Currie, 1968; Eyrolle et al., 2018)._All the measured concentrations were corrected for radioactive decay to the sampling date.

\section{Results}

\section{Variation of HTO contents}

172 The concentrations of HTO measured during this study were similar at Stations A and 173 B (Figure 2; Table S1ESM1) with respectively a mean HTO concentration of $1.1 \mathrm{~Bq} \cdot \mathrm{Bq} \mathrm{L}^{-1}$ (with

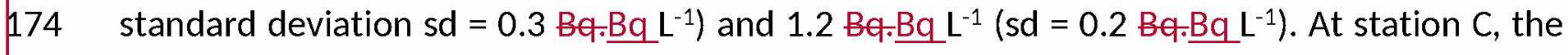
175 only value observed above the detection limit $\left(0.8 \pm 0.7 \mathrm{~Bq} \cdot \mathrm{Bq} \mathrm{L} \mathrm{L}^{-1}\right)$ was not significantly 176 different to the two upstream stations. The HTO concentration at this station remained very 177 low as several values were lower than the detection limit. For these three stations, no 178 significant variation of HTO contents were observed during the flushing operations. At station 179 D, two significant increases were observed during the flushing operation the 06/05/2012 and

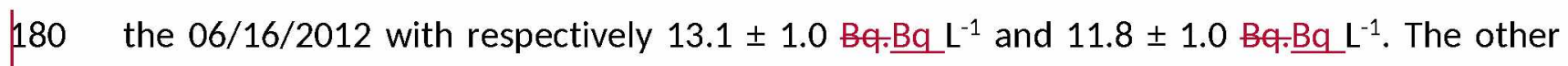
181 concentrations measured at station D were similar to the values observed at the other stations 182 with $1.1 \mathrm{~Bq} \cdot \underline{\mathrm{Bq}} \mathrm{L}^{-1}\left(\mathrm{sd}=0.3 \mathrm{~Bq} \cdot \mathrm{Bq} \mathrm{L}^{-1}\right)$. 

During the period studied, OBT contents ranged from $180 \pm 40 \mathrm{~Bq} \cdot \underline{\mathrm{Bq} \mathrm{L}^{-1} \mathrm{cw}}$ to $11,700 \pm$ 2,300 Bq. $\underline{\mathrm{Bq}} \mathrm{L}^{-1} \mathrm{cw}$ (Figure 3 - Table S3ESM2) with a mean value of $1,640 \mathrm{~Bq} \cdot \underline{\mathrm{Bq}} \mathrm{L}^{-1} \mathrm{cw}(\mathrm{sd}=2,600$ $\left.186 \mathrm{~Bq} \cdot \mathrm{Bq} \mathrm{L}^{-1} \mathrm{cw}\right)$. The mean $\mathrm{OBT}$ concentration at stations $\mathrm{A}$ and $\mathrm{B}$ were similar with respectively $187850 \mathrm{~Bq} \cdot \mathrm{Bq} \mathrm{L}_{\mathrm{cw}}^{-1}\left(\mathrm{sd}=320 \mathrm{~Bq} \cdot \underline{\mathrm{Bq} \mathrm{L}} \mathrm{L}_{\mathrm{cw}}\right)$ and $890 \mathrm{~Bq} \cdot \underline{\mathrm{Bq} \mathrm{L}^{-1} \mathrm{cw}}\left(\mathrm{sd}=330 \mathrm{~Bq} \cdot \underline{\mathrm{Bq} \mathrm{L}^{-1} \mathrm{cw}}\right)$ while significant 188 variations of OBT were observed at the two other stations. At station $\mathrm{C}$, the first value 189 measured was significantly higher than the other with $11,700 \pm 2,300 \mathrm{~Bq} \cdot \mathrm{Bq} \mathrm{L}^{-1} \mathrm{cw}$ observed the 06/09/12, then decreased to reach similar level than the upstream stations A and B. At station D, a high concentration of OBT was observed $48 \mathrm{~h}$ afterwards that of station C $(6,670 \pm 340$ $192 \mathrm{~Bq} \cdot \mathrm{Bq} \mathrm{L} \mathrm{L}^{-1} \mathrm{cw}$ the $06 / 11 / 12$ ). The other values measured during dam flushing operations (mean $\left.193=680 \mathrm{sd} 400 \mathrm{~Bq} \cdot \mathrm{Bq} \mathrm{L}^{-1} \mathrm{cw}\right)$ were similar to those of station $\mathrm{A}$ and $\mathrm{B}$.

Silt particles always constituted the major part of the SPM whatever the station with proportions ranging from 35.8 to $94.2 \%$ (Table ESM2). Sand particles were mostly observed at stations A and B, close to the studied dams. Those particles were rapidly stored in the Upper

197 Rhône River as the proportion of sand were very low at Stations C and D. The POC concentration observed at Station $\mathrm{A}$ and $\mathrm{C}$ remained constant while some variations were 199 observed at the two other stations (Table ESM2). Maximal concentration was observed at Station D with $36.0 \pm 1.8 \mathrm{mg} \mathrm{kg}^{-1}$.

\section{Discussion}

Most of the HTO concentrations measured at the four stations were similar to those observed from 2003 to 2015 by the Swiss Federal office of public health (OFSP, 2015) in water 205 samples collected near station $\mathrm{A}\left(1.03 \mathrm{~Bq} \cdot \underline{\mathrm{Bq}} \mathrm{L}^{-1}\right.$ with $\left.\mathrm{sd}=0.41 \mathrm{~Bq} \cdot \underline{\mathrm{Bq}} \mathrm{L}^{-1}\right)$ and not affected by 
the natural background in waters of French pristine rivers (Ducros et al., 2018). Although, the

208

increases observed at station D was strictly related to the releases of HTO by the NPP and not related to the dam flushing operations. As mentioned in the introduction, NPPs are allowed to release radionuclides into river systems conforming to liquid flow rate thresholds. The sampling performed at station D for this study was conducted during short radionuclide release operations with 12 events from 3 to 12 hours (Electricité De France, personal communication). The absence of higher HTO concentrations in the other samples of station D was due to the time lapse between the NPP's release operations and the samplings, performed 10 hours after the end of the operations. The transit time between the NPP and the sampling station has been validated by modeling using the hydrological model CASTEAUR (Beaugelin-Seiller et al., 2002). The increase was only observed at station D as the NPP is downstream the other stations (Figure 1). Overall, the values measured during this NPP's operations were similar to the mean concentrations recorded during radionuclide release operations at this NPP from 2011 to 2014 (12 Bq.Bq $L^{-1}$ ) (IRSN, 2015). Therefore, despite the input of high quantity of water from the flushing operations and characterized by a lower level of HTO than from the NPP releases, no significant effect of dilution was observed. In the Upper Rhône River, dam flushing operations do not affect HTO concentrations in the water column and, in the absence of NPP releases, these concentrations remain similar from upstream to downstream. Thus, in contrast with certain trace metals remobilized during such events such as arsenic (Bretier et al., 2019; Monnin et al., 2018), no significant transfer of tritium from sediment remobilization to the dissolved phase was observed. Moreover, these results did not show any significant contribution of tritium either from HTO potentially stored in the pore waters of remobilized sediments, or from OBT associated to fine particles $(<0.45 \mu \mathrm{m})$ towards waters. 
2334 to $\left.30,200 \mathrm{~Bq} \cdot \mathrm{Bq} \mathrm{L}^{-1} \mathrm{cw}\right)$ and confirmed the high variability due to the presence of tritiated 234 technogenic particles in the Rhône River. In fact, OBT concentrations are generally expected 235 to be rather close to HTO concentrations in most other cases (Eyrolle-Boyer et al., 2015). For example, in the sediments of the Rhône's tributaries not affected by luminous paints, 237 background values were lower than $10 \mathrm{~Bq} \cdot \mathrm{Bq}^{-1} \mathrm{cw}$ (Eyrolle et al., 2018). Since neither significant temporal nor spatial trends were observed in OBT concentrations, we hypothesize that these results can be explained by the heterogeneous distribution of technogenic tritium in suspended or deposited sedimentary particles leading to large variations of tritium 241 concentrations within the samples even though collected in areas close to each other. Also, 242 this result is confirmed by the absence of relation between OBT and POC concentrations. In 243 the Rhône River, OBT is not only bound to organic matter of natural origin, but would very 244 likely be trapped inside fine polystyrene particles from technogenic tritium (Eyrolle et al., 2018). Regarding grain size, any specific relation was observed but the highest level of OBT at Jons ( $\left.6670 \mathrm{~Bq} \mathrm{~L} \mathrm{~L}^{-1} \mathrm{cw}\right)$ was observed in a sample characterized by a high level of sand $(42.2 \%)$ (Table ESM2). This result highlights that these tritiated particles most probably come from the sediment stored in the dams and flushed during the operations. It also confirms their heterogeneously distribution as such increase of OBT concentration was not observed in

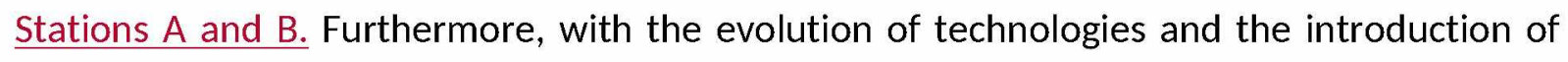
251 guidelines for the protection of the environment (Morereau et al., in prep.), OBT should no 252 longer be emitted at this level in the environment and its occurrence should be mainly related 253 to its long-time presence in the sediments of the Rhône River (Eyrolle et al., 2018). The highest 254 concentrations observed below the dams might be related to the resuspension of old 
contaminated sediments stored in the studied dams as observed for PAHs by Lepage et al.

256 (2020). The OBT is expected to be transported downstream and its concentration should 257 decrease from upstream to downstream in the following decades.

\section{Conclusion}

The consequences of dam flushing operations on tritium concentrations were 261 investigated in the Rhône River downstream Lake Geneva by characterizing the HTO and OBT concentrations respectively in filtered water and suspended particulate matter (SPM) samples collected downstream three dams flushed in June 2012. Our results demonstrate that dam flushing operations do not significantly affect tritium concentrations in the water column as they remained similar to those previously recorded during normal flow conditions. Analyses of OBT in the SPM demonstrated transient increases in concentration during the-dam flushing operations. This increase wasthose are most probably linked explained byto the resuspension of fine tritiated particles from watchmaking activities. As the increases were transient and not observed at all the stations, no significant temporal nor spatial trend following dam flushing operations can be drawn clearly-trend could be linked to the dam flushing operations. However, OBT is heterogeneously distributed in sediments of the Rhône River and SPM-and-z 272 large amounts of ӨBT this radionuclide are stillmight be currently stored in the Upper Rhône 273 River sediments. Extreme events and could be redistributed following extreme events-such as 274 dam flushing operations can redistribute these storages to the downstream part of the River. 275 The radiotoxicity of free tritium (HTO) or organically bound tritium to naturally occurring 276 organic compounds (OBT) are low comparing to most other natural or artificial radionuclides. 277 Nevertheless, the specific radiotoxicity of organically bound tritium to synthetic organic 278 particles are unknown to our knowledge as well as their transfer rates toward living organisms. 


\section{Acknowledgements}

This study was supported by the Rhône Sediment Observatory (OSR), a multi-partner research program partly funded by the Rhône Plan and by the European Regional Development Fund (ERDF) allocated by the European Union. We thank the teams of OSR, especially those of INRAE and CEREGE, for their contribution in the field for water and sediment sampling. We are very grateful to CNR, DREAL ARA, SIG and EDF services for cooperating with OSR and sharing their monitoring data.

\section{References}

AFNOR, 2009. NF ISO 10694: Particle Size Analysis - Laser Diffraction Methods. 51 pp.

AFNOR, 1995. NF ISO 10694: Soil quality - Determination of organic and total carbon after dry combustion (elementary analysis). $7 \mathrm{pp}$.

Beaugelin-Seiller, K., Boyer, P., Garnier-Laplace, J., Adam, C., 2002. Casteaur: A simple tool to assess the transfer of radionuclides in waterways. Health Phys. 83, 539-542. https://doi.org/10.1097/00004032-200210000-00013

Bravard, J.-P., Clémens, A., 2008. Le Rhône en 100 questions. Méditerranée (report in French) $295 \mathrm{pp}$.

Bretier, M., Dabrin, A., Bessueille-Barbier, F., Coquery, M., Barbier-Bessueille, F., Coquery, M., 2019. Comparison of integrative passive sampling and discrete monitoring to assess the impact of dam flushing event on dissolved trace elements concentrations. Sci. Total Environ. 656, 433-446. https://doi.org/10.1016/j.scitotenv.2018.11.303

Brown, C.B., 1944. The control of reservoir silting. US Gov. Print. Off. 521, 168 pp.

Ciffroy, P., Siclet, F., Damois, C., Luck, M., 2006. A dynamic model for assessing radiological consequences of tritium routinely released in rivers. Application to the Loire River. J. 
Cossonnet, C., Neiva Marques, A.M., Gurriaran, R., 2009. Experience acquired on environmental sample combustion for organically bound tritium measurement. Appl. Radiat. Isot. 67, 809-811. https://doi.org/10.1016/j.apradiso.2009.01.039

Currie, L.A., 1968. Limits for Qualitative Detection and Quantitative Determination: 307 Application to Radiochemistry. Anal. Chem. 40, 586-593. https://doi.org/10.1021/ac60259a007

Ducros, L., Eyrolle, F., Vedova, C. Della, Charmasson, S., Leblanc, M., Mayer, A., Babic, M., 672-682. https://doi.org/10.1016/j.scitotenv.2017.08.026

Eisenbud, M., Bennett, B., Blanco, R.E., 1979. Tritium in the environment. NCRP Report No. 62. Behav. Tritium Environ.

Eyrolle-Boyer, F., Boyer, P., Claval, D., Charmasson, S., Cossonnet, C., 2014. Apparent enrichment of organically bound tritium in rivers explained by the heritage of our past. J. Environ. Radioact. 136, 162-168. https://doi.org/10.1016/j.jenvrad.2014.05.019

Eyrolle-Boyer, F., Claval, D., Cossonnet, C., Zebracki, M., Gairoard, S., Radakovitch, O., Calmon, P., Leclerc, E., 2015. Tritium and 14C background levels in pristine aquatic systems and their potential sources of variability. J. Environ. Radioact. 139, 24-32.

Eyrolle, F., Lepage, H., Copard, Y., Ducros, L., Claval, D., Saey, L., Cossonnet, C., Giner, F., Mourier, D., 2018. A brief history of the origins and contents of Organically Bound Tritium (OBT) and 14C in the sediments of the Rhône watershed. Sci. Total Environ. in review, 
Fruchard, F., Camenen, B., 2012. Reservoir sedimentation: different type of flushing-friendly flushing example of genissiat dam flushing. ICOLD Int. Symp. Dams a Chang. world 6 pp.

IRSN, 2015. Bilan de l'état radiologique de l'environnement français de juin 2011 à décembre 2014. PRP-ENV (french report) 253p.

IRSN, 2013. Constat radiologique Vallée du Rhône. Rapport final relatif au milieu aquatique. PRP-ENV/SESURE (french report) 37, 68p.

Jean-Baptiste, P., Baumier, D., Fourré, E., Dapoigny, A., Clavel, B., 2007. The distribution of tritium in the terrestrial and aquatic environments of the Creys-Malville nuclear power plant (2002-2005). J. Environ. Radioact. 94, 107-118. https://doi.org/10.1016/j.jenvrad.2007.01.010

Jean-Baptiste, P., Fontugne, M., Fourré, E., Marang, L., Antonelli, C., Charmasson, S., Siclet, F., 2018. Tritium and radiocarbon levels in the Rhône river delta and along the French Mediterranean coastline. J. Environ. Radioact. 187, 53-64. https://doi.org/10.1016/j.jenvrad.2018.01.031

Kalnejais, L.H., Martin, W.R., Bothner, M.H., 2010. The release of dissolved nutrients and metals from coastal sediments due to resuspension. Mar. Chem. 121, 224-235. https://doi.org/10.1016/j.marchem.2010.05.002

Kim, S.B., Baglan, N., Davis, P.A., 2013. Current understanding of organically bound tritium (OBT) in the environment. J. Environ. Radioact. 126, 83-91. https://doi.org/10.1016/j.jenvrad.2013.07.011

Krejci, K., Zeller, J., 1979. Tritium pollution in the Swiss luminous compound industry, in: International Symposium on the Behaviour of Tritium in the Environment. IAEA, Vienna, pp. 65-77.

Launay, M., 2014. Flux de matières en suspension, de mercure et de PCB particulaires dans le 
Rhône, du Léman à la Méditerranée. Thesis (in French) 434.

Lepage, H., Launay, M., Le Coz, J., Angot, H., Miège, C., Gairoard, S., Radakovitch, O., Coquery, M., 2020. Impact of dam flushing operations on sediment dynamics and quality in the upper Rhône River, France. J. Environ. Manage. 255, 109886. https://doi.org/10.1016/j.jenvman.2019.109886

Masson, M., Angot, H., Le Bescond, C., Launay, M., Dabrin, A., Miège, C., Le Coz, J., Coquery, M., 2018. Sampling of suspended particulate matter using particle traps in the Rhône Environ. 637-638, 538-549. https://doi.org/10.1016/j.scitotenv.2018.04.343

Monnin, L., Ciffroy, P., Garnier, J.M., Ambrosi, J.P., Radakovitch, O., 2018. Remobilization of trace metals during laboratory resuspension of contaminated sediments from a dam reservoir. J. Soils Sediments 18, 2596-2613. https://doi.org/10.1007/s11368-018-19315

Morereau, A., Lepage, H., Claval, D., Cossonnet, C., Radakovitch, O., Ambrosi, J.-P., Mourier, B., Eyrolle, F., n.d. Technogenic tritium contamination from watchmaking industry and its

OFSP, 2015. Radenviro.ch [WWW Document]. URL http://www.radenviro.ch/fr$\mathrm{CH} /$ measures/274 (accessed 7.5.16).

Peter, D.H., Castella, E., Slaveykova, V.I., 2014. Effects of a reservoir flushing on trace metal partitioning, speciation and benthic invertebrates in the floodplain. Environ. Sci. Process. Impacts 16, 2692-2702. https://doi.org/10.1039/c4em00387j management of sediment fluxes in reservoir by environmental friendly flushing : the case 
study of the Genissiat dam on the upper Rhone River (France), in: 12th International Conference on River Sedimentation. Kyoto (Japan), pp. 1147-1156.

Poulier, G., Launay, M., Le Bescond, C., Thollet, F., Coquery, M., 2019. Combining flux monitoring and estimation to establish annual budgets of suspended particulate matter and associated pollutants in the Rhône River from Lake Geneva to the Mediterranean Sea. Sci. Total Environ. 658, 457-473. https://doi.org/10.1016/J.SCITOTENV.2018.12.075

Provansal, M., Dufour, S., Sabatier, F., Anthony, E.J., Raccasi, G., Robresco, S., 2014. The geomorphic evolution and sediment balance of the lower Rhône River (southern France) over the last 130years: Hydropower dams versus other control factors. Geomorphology 219, 27-41. https://doi.org/10.1016/j.geomorph.2014.04.033

Schulze, T., Ricking, M., Schröter-Kermani, C., Körner, A., Denner, H.-D., Weinfurtner, K., Winkler, A., Pekdeger, A., 2007. The German Environmental Specimen Bank - Sampling, processing, and archiving sediment and suspended particulate matter. J. Soils Sediments 7, 361-367. https://doi.org/10.1065/jss2007.08.248

Schürch, M., Kozel, R., Schotterer, U., Tripet, J.-P.P., Sch??rch, M., Kozel, R., Schotterer, U., Tripet, J.-P.P., 2003. Observation of isotopes in the water cycle-the Swiss National Network (NISOT). Environ. Geol. 45, 1-11. https://doi.org/10.1007/s00254-003-0843-9

Syvitski, J.P.M., Vörösmarty, C.J., Kettner, A.J., Green, P., 2005. Impact of humans on the flux of terrestrial sediment to the global coastal ocean. Science (80-. ). 308, 376-380. https://doi.org/10.1126/science.1109454

Thollet, F., Le Bescond, C., Lagouy, M., Gruat, A., Grisot, G., Le Coz, J., Coquery, M., Lepage, H., Gairoard, S., Gattacceca, J.C., Ambrosi, J.-P., Radakovitch, O., 2018. Observatoire des sédiments du Rhône. https://doi.org/10.17180/OBS.OSR

Ueda, S., Hasegawa, H., Kakiuchi, H., Ochiai, S., Akata, N., Hisamatsu, S., 2015. Nuclear 

accident-derived ${ }^{3} \mathrm{H}$ in river water of Fukushima Prefecture during 2011-2014. J. Environ. Radioact. 146, 102-109. https://doi.org/10.1016/j.jenvrad.2015.04.014

400 


\section{Highlights}

- Tritium were monitored during dam regulations in the Rhone River.

- Dam flushing operations had no impact on HTO concentration in water.

- Increase of HTO contents were only related to the releases from a nuclear plant.

- Flushing operations resuspended contaminated sediments by watches industries.

- Sporadic high OBT contents in SPM reflect its heterogeneous distribution. 


\section{Abstract}

Tritium is a radionuclide commonly observed worldwide in riverine systems. In the Rhône River downstream the Lake Geneva (Switzerland and France), its occurrence is also related to its use for its luminescent properties in watchmaking paints. In fact, tritium is regularly observed at anomalous levels in this river and extreme events such as flushing operations might conduct to its transport downstream. In the Rhône River, characterized by 21 dams downstream the Geneva Lake, such operations are regularly organized to remove the sediments and limit problematic consequences such as siltation and increased flooding hazards. The consequences of dam flushing operations on tritium concentrations were thus investigated. Samples of Suspended Particulate Matter (SPM) and water were collected in the Rhone River downstream of Geneva in June 2012, during a planned flushing operation of three upstream reservoirs (Verbois, Chancy-Pougny and Génissiat). The concentrations of tritiated water ( $\mathrm{HTO}$ ) and organically bound Tritium (OBT) were measured and compared to reference concentrations. The flushing operations had no impact on the HTO concentration while the increases observed were related to the authorized releases of HTO from a nuclear power plant located downstream the dams. High increases of OBT concentrations in SPM were observed at two stations (Creys-Malville and Jons) without clear spatial or temporal trends. These anomalous peaks could be explained by the heterogeneous spatial distribution of technogenic tritium leading to large variations of tritium concentrations within the samples even though collected in areas close to each other. The results highlight the need to investigate the amount of such technogenic tritium currently stored in the upstream Rhone River as it might be significant. 


\section{Before dam flushing operation}

Suspended sediment

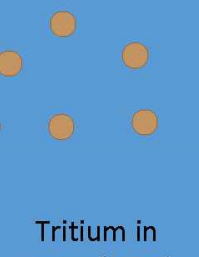

water (HTO)

Dam

Freshly deposited sediment ,

Tritium in sediment (OBT)
After dam flushing operation

Spatial variation of tritium during the flushing operations

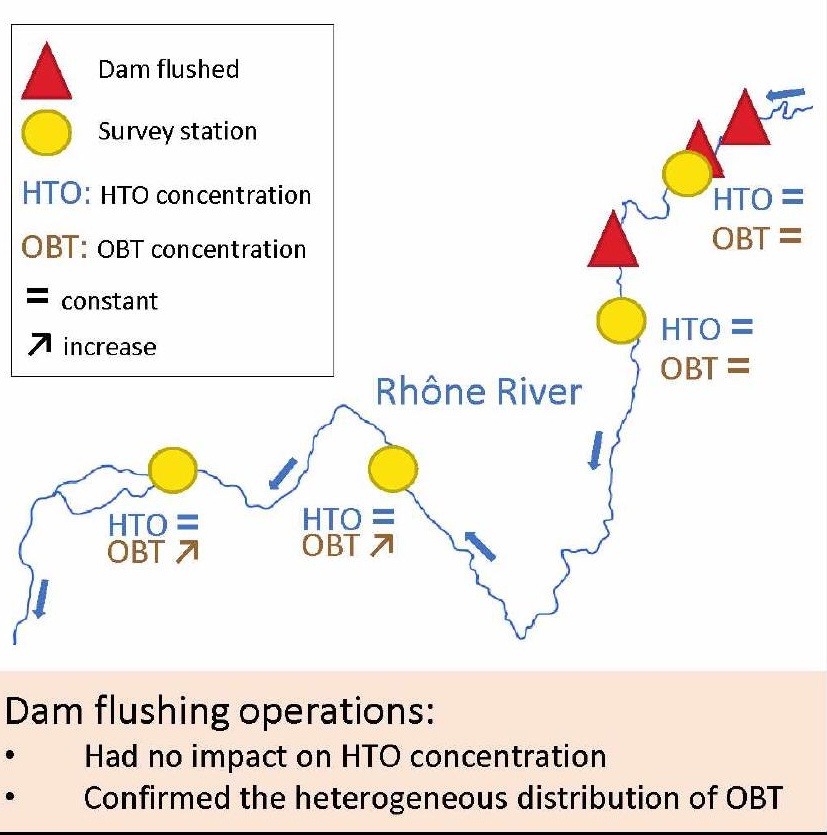




\section{Spatial and temporal variation of tritium concentrations during a}

2 dam flushing operation

3 Lepage Hugo $^{a^{*}}$, Eyrolle Frédérique ${ }^{a}$, Ducros Loï ${ }^{b}$, Claval Davida.

4

5 a Institut de Radioprotection et de Sureté Nucléaire (IRSN), PSE-ENV, SRTE/LRTA,

6 SEREN/LEREN, BP 3, 13115 Saint-Paul-lez-Durance, France

7

8 b Université de Nîmes, EA7352 CHROME, Laboratoire GIS, Parc scientifique et technique G.

9 Besse, 150 rue Georges Besse, 30000 Nîmes, France

10

$11{ }^{*}$ corresponding author 


\section{Spatial and temporal variation of tritium concentrations during a \\ 2 dam flushing operation}

3 Abstract

4 Tritium is a radionuclide commonly observed worldwide in riverine systems. In the Rhône

5 River downstream the Lake Geneva (Switzerland and France), its occurrence is also related to

6 its use for its luminescent properties in watchmaking paints. In fact, tritium is regularly

7 observed at anomalous levels in this river and extreme events such as flushing operations

8 might conduct to its transport downstream. In the Rhône River, characterized by 21 dams

9 downstream the Geneva Lake, such operations are regularly organized to remove the sediments and limit problematic consequences such as siltation and increased flooding hazards. The consequences of dam flushing operations on tritium concentrations were thus investigated. Samples of Suspended Particulate Matter (SPM) and water were collected in the Rhone River downstream of Geneva in June 2012, during a planned flushing operation of three upstream reservoirs (Verbois, Chancy-Pougny and Génissiat). The concentrations of tritiated water (HTO) and organically bound Tritium (OBT) were measured and compared to reference concentrations. The flushing operations had no impact on the HTO concentration while the increases observed were related to the authorized releases of HTO from a nuclear power plant located downstream the dams. High increases of OBT concentrations in SPM were observed at two stations (Creys-Malville and Jons) without clear spatial or temporal trends. These anomalous peaks could be explained by the heterogeneous spatial distribution of technogenic tritium leading to large variations of tritium concentrations within the samples even though collected in areas close to each other. The results highlight the need to investigate the amount 
of such technogenic tritium currently stored in the upstream Rhone River as it might be significant.

\section{Keywords}

Radionuclide; Technogenic tritium; organically bound Tritium; sediment; suspended particulate matter; watchmaking paint

\section{Introduction}

Tritium $\left({ }^{3} \mathrm{H}\right.$ - half-life $=12.3$ years $)$ is a radionuclide commonly observed for several decades in the environment (Eisenbud et al., 1979). In rivers, ${ }^{3} \mathrm{H}$ can be liquid (tritiated water - HTO) or incorporated in particulate organic compounds (Organically Bound Tritium - OBT) (Kim et al., 2013). The HTO is the predominant form of tritium in the environment and it closely follows the water cycle (Ciffroy et al., 2006; Eyrolle-Boyer et al., 2015). It is commonly used as a tracer in hydrogeology and marine studies (Ducros et al., 2018). The HTO is also the most released aqueous radionuclide from nuclear facilities, with levels of activity currently 1000 times higher than the sum of artificial gamma emitters discharged (Eyrolle et al., 2018). In fact, in compliance with the legislation, the nuclear sector is allowed to release low-activity liquid effluent into rivers. The OBT is part of the organic matter cycle and has been measured in sediments and suspended particulate matter (SPM) for decades (Eyrolle et al., 2018). Some of the OBT do not easily exchange with the surrounding water molecules and persist in the environment until organic compounds are biodegraded. These forms of tritium are expected to be stored in sediments associated with particulate organic matter (Eyrolle-Boyer et al., 2014) and might be affected by extreme events such as flood events or dam flushing operations. In fact, these events strongly affect the behavior of dissolved and particulate contaminants including tritium. For example, after the deposition of tritium following the 
Fukushima accident in march 2011, HTO concentrations in two small mountainous rivers were shown to be higher during flood events than in baseflow conditions (Ueda et al., 2015) but decreased rapidly the following years to reach background concentration in 2014. Dams on rivers considerably impact SPM transport, by reducing flow velocity and increasing SPM deposition (Syvitski et al., 2005) and that of their related contaminants (Lepage et al., 2020). Contaminants associated with deposited sediments may also be resuspended and disseminated (Peter et al., 2014) or transferred to the dissolved phase (Bretier et al., 2019; Kalnejais et al., 2010).

In France, the Rhône River is characterized by the presence of 21 hydropower plants and is one of the most nuclearized rivers in the world, with 5 nuclear power plants (NPP) including one in dismantlement, nuclear fuel production, reprocessing plants and research laboratories. From 0.2 to $0.610^{9} \mathrm{~kg}$ of SPM are stored each year along the Rhône River (Bravard and Clémens, 2008), mostly in dam reservoirs (Provansal et al., 2014). Resuspension processes, such as dam flushing operations, are regularly organized to remove stored sediments and limit problematic consequences such as siltation and increased flooding hazards (Brown, 1944; Peteuil et al., 2013). Such dam operations lead either to the resuspension of contaminated sediments stored in the dams, or to the dilution of contaminated SPM by flushing non-contaminated sediments (Lepage et al., 2020).

Moreover, in the past century, most of the OBT was originate from other industrial plants present in the Rhône River and especially in its upstream part that produced luminescent paint used in watches (Eyrolle et al., 2018; Jean-Baptiste et al., 2018). These companies have released fine particles of tritiated compounds (usually tiny tritiated polystyrene spherules a few tens of microns in diameter) used in luminous paints (JeanBaptiste et al., 2007; Krejci and Zeller, 1979; Schürch et al., 2003). In fact, these tritiated 
technogenic particles (hot tritiated particles) could have been released directly into the river by the industrial plants, or transferred into the environment during the waste incineration process, or finally progressively transferred due to soil erosion (Schürch et al., 2003). These refractory particles that accumulate in sediments are expected to persist in the environment for a very long time (Eyrolle et al., 2018; Morereau et al., in prep.) and have also been observed in the Mediterranean Sea near the outlet of the Rhône River (Jean-Baptiste et al., 2018). Although a recent review written by Eyrolle et al. (2018) summarized results on its specific behavior in the Rhône River, reports on the impact of hydrological events on OBT concentrations remain rare especially its dynamics during dam flushing operations.

This field study was conducted in the Rhône River downstream the Lake Geneva during the flushing operations of several dams in June 2012. Water and SPM samples were collected at different locations for different periods. The tritium concentrations were characterized and the results were then compared with the contents recorded before the event.

\section{Materials and Method}

\section{Dam location and description of the flushing operations}

This study was conducted along the Upper Rhône River in France and Switzerland, downstream the Lake Geneva (Figure 1). This basin $\left(95,600 \mathrm{~km}^{2}\right.$ at Beaucaire station) constitutes the main SPM input flowing into the Western Mediterranean Sea with a mean SPM flux of $6.5 \mathrm{Mt}^{\text {year-1 }}{ }^{-1}$ from 2000 to 2015 (Poulier et al., 2019). This work focuses on flushing operations conducted in June 2012 in three reservoirs located downstream of Lake Geneva in Switzerland (Figure 1): Verbois, Chancy-Pougny, and Génissiat. These flushing operations are described in Lepage et al. (2020). In brief, the water level of the three dams was lowered following the drawdown flushing method (Fruchard and Camenen, 2012) in order to remove 
stored sediments. The large-volume Génissiat reservoir located downstream of the two other dams was flushed first (4-12 June 2012) in order to compensate for the deposition of the SPM released from the Chancy-Pougny (9-16 June 2012) and Verbois dams (9-22 June 2012). Discharge varied from $129 \mathrm{~m}^{3} \mathrm{~s}^{-1}$ to $631 \mathrm{~m}^{3} \mathrm{~s}^{-1}$ in the vicinity of Chancy-Pougny during the flushing periods (Figure ESM1 in electronic supplementary materials). Discharge increased from upstream to downstream and reached maximal values $\left(1600 \mathrm{~m}^{3} \mathrm{~s}^{-1}\right)$ at Jons (Station $D$ in Figure 1) on the $06 / 14$, which correspond to discharges observed for biennial flood (Lepage et al., 2020). SPM concentration reached $16.6 \mathrm{~g} \mathrm{~L}^{-1}$ near Génissiat during its flushing and the highest SPM concentration was observed during the flushing of Verbois and Chancy-Pougny with $48.6 \mathrm{~g} \mathrm{~L}^{-1}$ observed at Chancy-Pougny (Figure ESM1 in electronic supplementary materials). The SPM concentrations decreased with distance and the maximum concentrations observed at Jons was $0.9 \mathrm{~g} \mathrm{~L}^{-1}$. It has to be noted that floods occurred in two tributaries (Ain and Fier - Figure 1) with a limited impact on the transport of SPM (Launay, 2014; Lepage et al., 2020).

\section{Sampling and samples}

To characterize the impact of the dam flushing operations on the concentrations of HTO (water samples) and OBT (SPM samples), samples were collected at four stations (Figure 1, Table 1) with different sampling periods due to logistic constrain:

- Station A at Pougny, in the downstream vicinity of Chancy-Pougny and Verbois dams. Samples were collected from the 06/09/2012 to the 06/20/2012 during the flushing operations of these two dams.

- Station B at Seyssel, downstream Génissiat dam and during its flushing operation with samples collected from the $06 / 04 / 2012$ to the $06 / 10 / 2012$. 
- Station C at Creys-Malville in a monitoring station used to supply the regulatory control of the releases from NPPs (IRSN, 2015) and used in this study for temporal comparison. Sampling was conducted before, during and after the flushing operations, from the $05 / 25 / 2012$ to the $07 / 01 / 2012$.

- Station D at Jons in a monitoring station (Masson et al., 2018; Thollet et al., 2018) located downstream a NPP (Figure 1) with samples collected for the main period of flushing operations, from the 06/04/2012 to the 07/03/2012.

wo different sampling methods were used to collect water samples (Table 1). Instantaneous water samples were obtained manually using a stainless-steel bucket (approx. $4 \mathrm{~L}$ ) at stations A, B and D, and by an Automatic Water Sampler (AWS) at station C. The AWS used for water sampling was a Bühler 4011 (HachLange, Germany) and set to collect $10 \mathrm{~mL}$ every 65 minutes to constitute time integrated raw water samples (6 days) stored in glass bottles. Samples were all stored in dark glass bottles at $4^{\circ} \mathrm{C}$ until analyses.

For OBT measurement, SPM samples were collected using Particle Trap (PT). These samplers were built following the German Environmental Specimen Bank model (Masson et al., 2018; Schulze et al., 2007). Water flows through the high-quality stainless steel box and its velocity is reduced by two baffles. SPM settle in two sedimentation basins in the box. Samples were collected every 1 to 4 days (see Table ESM1 in electronic supplementary materials). Due to logistic constrain, the PT were set on the bottom of the river at Stations A, B and D while at Station C it was approx. $50 \mathrm{~cm}$ below the surface. Prior to analysis, SPM samples were stored in the dark at $4^{\circ} \mathrm{C}$, deep-frozen, freeze-dried, and homogenized through a $2 \mathrm{~mm}$ stainless steel sieve. Dried samples were then immediately sealed under soft vacuum in aluminized bags until analyses in order to avoid the exchange of water molecules with the atmosphere. 
140

141

142

143

144

145

146

147

148

149

150

151

152

154

155

156

157

158

159

160

161

162

\section{Grain-size distribution}

For the measure of volumetric grain size distribution, a representative aliquot of each wet sample was taken before processing and was analyzed on a CILAS 1190 laser particle size analyzer (Masson et al., 2018) according to the ISO 13320 standard method (AFNOR, 2009). Clay $(<1.95 \mu \mathrm{m})$, Silt $(<63 \mu \mathrm{m})$ and Sand $(<2000 \mu \mathrm{m})$ were estimated.

\section{Particulate Organic Carbon analysis}

The determination of Particulate Organic Carbon (POC) in SPM samples was performed using a carbon analyzer (Thermo Electron, CHN Flash 2000) by INRA laboratory (Arras, France). Decarbonation was completed using hydrochloric acid according to the NF ISO 10694 standard method (AFNOR, 1995). The limit of quantification (LQ) was estimated to be $0.05 \mathrm{~g} \mathrm{~kg}^{-1}$ and analytical uncertainty varied between $\sim 3 \%$ and $\sim 6 \% \quad(k=2)$, depending on the POC concentration.

\section{Tritium analyses}

The concentrations of the two main forms of tritium (HTO and OBT) were investigated.

The HTO analyses were performed on $20 \mathrm{ml}$ of filtered water $(<0.2 \mu \mathrm{m})$ either directly filtered in the field for punctual samples or in the laboratory for time-integrated ones sampled by AWS. Filtered waters were analyzed by classical scintillation counting for HTO content (Tricarb $3180 \mathrm{TR} / \mathrm{SL}$ ), by taking an aliquot of $10 \mathrm{~mL}$ and adding $10 \mathrm{~mL}$ of scintillation liquid (UltimaGold LLT).

OBT analyses were conducted using the Helium-3 ingrowth method after placing the sample in a vacuum (10-6 mbar) and storing it for 3 to 4 months (Cossonnet et al., 2009). The Helium-3 is a decay product of tritium-and its concentration is measured by mass spectrometry (Jean-Baptiste et al., 2010). OBT concentrations were converted in Becquerel 
163

164

165

166

167

per liter of combustion water $\left(\mathrm{Bq} \mathrm{L}^{-1} \mathrm{cw}\right)$ by using the percentage of hydrogen measured in each sample by a CHNS elemental analyzer (Elementar, vario MICROcube).

For both methods, detection limit was around $0.6 \mathrm{~Bq} \mathrm{~L}^{-1}$ with a detection threshold of 1.2 Bq L $\mathrm{L}^{-1}$ (Currie, 1968; Eyrolle et al., 2018). All the measured concentrations were corrected for radioactive decay to the sampling date.

\section{Results}

\section{Variation of HTO contents}

The concentrations of HTO measured during this study were similar at Stations A and B (Figure 2; Table ESM1) with respectively a mean HTO concentration of $1.1 \mathrm{~Bq} \mathrm{~L}^{-1}$ (with standard deviation $\left.\mathrm{sd}=0.3 \mathrm{~Bq} \mathrm{~L}^{-1}\right)$ and $1.2 \mathrm{~Bq} \mathrm{~L}^{-1}\left(\mathrm{sd}=0.2 \mathrm{~Bq} \mathrm{~L}^{-1}\right)$. At station $\mathrm{C}$, the only value observed above the detection limit $\left(0.8 \pm 0.7 \mathrm{~Bq} \mathrm{~L}^{-1}\right)$ was not significantly different to the two upstream stations. The HTO concentration at this station remained very low as several values were lower than the detection limit. For these three stations, no significant variation of HTO contents were observed during the flushing operations. At station D, two significant increases were observed during the flushing operation the 06/05/2012 and the 06/16/2012 with respectively $13.1 \pm 1.0 \mathrm{~Bq} \mathrm{~L}^{-1}$ and $11.8 \pm 1.0 \mathrm{~Bq} \mathrm{~L}^{-1}$. The other concentrations measured at station $\mathrm{D}$ were similar to the values observed at the other stations with $1.1 \mathrm{~Bq} \mathrm{~L}^{-1}(\mathrm{sd}=0.3 \mathrm{~Bq}$ $\left.\mathrm{L}^{-1}\right)$

OBT

$2,300 \mathrm{~Bq} \mathrm{~L}^{-1} \mathrm{cw}$ (Figure 3 - Table ESM2) with a mean value of $1,640 \mathrm{~Bq} \mathrm{~L}^{-1} \mathrm{cw}\left(\mathrm{sd}=2,600 \mathrm{~Bq} \mathrm{~L}^{-1} \mathrm{cw}\right)$. The mean OBT concentration at stations $\mathrm{A}$ and $\mathrm{B}$ were similar with respectively $850 \mathrm{~Bq} \mathrm{\textrm {L } ^ { - 1 } \mathrm { cw }}$ $\left(\mathrm{sd}=320 \mathrm{~Bq} \mathrm{~L}_{\mathrm{cw}}^{-1}\right)$ and $890 \mathrm{~Bq} \mathrm{~L}^{-1} \mathrm{cw}\left(\mathrm{sd}=330 \mathrm{~Bq} \mathrm{~L}^{-1} \mathrm{cw}\right)$ while significant variations of OBT were 
observed at the two other stations. At station $\mathrm{C}$, the first value measured was significantly higher than the other with $11,700 \pm 2,300 \mathrm{~Bq} \mathrm{~L}^{-1} \mathrm{cw}$ observed the $06 / 09 / 12$, then decreased to reach similar level than the upstream stations $A$ and $B$. At station $\mathrm{D}$, a high concentration of OBT was observed $48 \mathrm{~h}$ afterwards that of station $\mathrm{C}\left(6,670 \pm 340 \mathrm{~Bq} \mathrm{~L}^{-1} \mathrm{cw}\right.$ the $\left.06 / 11 / 12\right)$. The other values measured during dam flushing operations (mean $=680 \mathrm{sd} 400 \mathrm{~Bq} \mathrm{~L}^{-1} \mathrm{cw}$ ) were similar to those of station A and B. Silt particles always constituted the major part of the SPM whatever the station with proportions ranging from 35.8 to $94.2 \%$ (Table ESM2). Sand particles were mostly observed at stations A and B, close to the studied dams. Those particles were rapidly stored in the Upper Rhône River as the proportion of sand were very low at Stations $C$ and $D$. The POC concentration observed at Station $A$ and $C$ remained constant while some variations were observed at the two other stations (Table ESM2). Maximal concentration was observed at Station D with $36.0 \pm 1.8 \mathrm{mg} \mathrm{kg}^{-1}$.

\section{Discussion}

Most of the HTO concentrations measured at the four stations were similar to those observed from 2003 to 2015 by the Swiss Federal office of public health (OFSP, 2015) in water samples collected near station $\mathrm{A}\left(1.03 \mathrm{~Bq} \mathrm{~L}^{-1}\right.$ with $\left.\mathrm{sd}=0.41 \mathrm{~Bq} \mathrm{~L}^{-1}\right)$ and not affected by NPP releases. Furthermore, the concentrations remained in the range of values observed for the natural background in waters of French pristine rivers (Ducros et al., 2018). Although, the increases observed at station D was strictly related to the releases of HTO by the NPP and not related to the dam flushing operations. As mentioned in the introduction, NPPs are allowed to release radionuclides into river systems conforming to liquid flow rate thresholds. The sampling performed at station D for this study was conducted during short radionuclide 
release operations with 12 events from 3 to 12 hours (Electricité De France, personal communication). The absence of higher HTO concentrations in the other samples of station D

211 was due to the time lapse between the NPP's release operations and the samplings, 212 performed 10 hours after the end of the operations. The transit time between the NPP and

213 the sampling station has been validated by modeling using the hydrological model CASTEAUR 214 (Beaugelin-Seiller et al., 2002). The increase was only observed at station D as the NPP is downstream the other stations (Figure 1). Overall, the values measured during this NPP's operations were similar to the mean concentrations recorded during radionuclide release operations at this NPP from 2011 to 2014 (12 Bq L-1) (IRSN, 2015). Therefore, despite the input of high quantity of water from the flushing operations and characterized by a lower level of HTO than from the NPP releases, no significant effect of dilution was observed. In the Upper Rhône River, dam flushing operations do not affect HTO concentrations in the water column and, in the absence of NPP releases, these concentrations remain similar from upstream to downstream. Thus, in contrast with certain trace metals remobilized during such events such as arsenic (Bretier et al., 2019; Monnin et al., 2018), no significant transfer of tritium from sediment remobilization to the dissolved phase was observed. Moreover, these results did not show any significant contribution of tritium either from HTO potentially stored in the pore waters of remobilized sediments, or from OBT associated to fine particles $(<0.45 \mu \mathrm{m})$ towards waters.

Despite the high concentrations of OBT observed at stations $C$ and D, all the concentrations remained in the same range as those reported by Eyrolle et al., (2018) (from 4 to $30,200 \mathrm{~Bq} \mathrm{L^{-1 }} \mathrm{cw}$ ) and confirmed the high variability due to the presence of tritiated 231 technogenic particles in the Rhône River. In fact, OBT concentrations are generally expected 232 to be rather close to HTO concentrations in most other cases (Eyrolle-Boyer et al., 2015). For 
example, in the sediments of the Rhône's tributaries not affected by luminous paints, background values were lower than $10 \mathrm{~Bq} \mathrm{~L}^{-1} \mathrm{cw}$ (Eyrolle et al., 2018). Since neither significant 235 temporal nor spatial trends were observed in OBT concentrations, we hypothesize that these 236 results can be explained by the heterogeneous distribution of technogenic tritium in 237 suspended or deposited sedimentary particles leading to large variations of tritium 238 concentrations within the samples even though collected in areas close to each other. Also,

239 this result is confirmed by the absence of relation between OBT and POC concentrations. In the Rhône River, OBT is not only bound to organic matter of natural origin, but would very

241 likely be trapped inside fine polystyrene particles from technogenic tritium (Eyrolle et al., 242 2018). Regarding grain size, any specific relation was observed but the highest level of OBT at Jons ( $\left.6670 \mathrm{~Bq} \mathrm{~L}^{-1} \mathrm{cw}\right)$ was observed in a sample characterized by a high level of sand $(42.2 \%)$

244 (Table ESM2). This result highlights that these tritiated particles most probably come from the 245 sediment stored in the dams and flushed during the operations. It also confirms their 246 heterogeneously distribution as such increase of OBT concentration was not observed in 247 Stations A and B. Furthermore, with the evolution of technologies and the introduction of 248 guidelines for the protection of the environment (Morereau et al., in prep.), OBT should no 249 longer be emitted at this level in the environment and its occurrence should be mainly related 250 to its long-time presence in the sediments of the Rhône River (Eyrolle et al., 2018). The highest 251 concentrations observed below the dams might be related to the resuspension of old 252 contaminated sediments stored in the studied dams as observed for PAHs by Lepage et al. 253 (2020). The OBT is expected to be transported downstream and its concentration should 254 decrease from upstream to downstream in the following decades. 


\section{Conclusion}

The consequences of dam flushing operations on tritium concentrations were investigated in the Rhône River downstream Lake Geneva by characterizing HTO and OBT

259 concentrations respectively in filtered water and suspended particulate matter (SPM) samples 260 collected downstream three dams flushed in June 2012. Our results demonstrate that dam

261 flushing operations do not significantly affect tritium concentrations in the water column as 262 they remained similar to those previously recorded during normal flow conditions. Analyses 263 of OBT in the SPM demonstrate transient increases in concentration during dam flushing 264 operations. Those are most probably explained by the resuspension of fine tritiated particles 265 from watchmaking activities. As the increases were transient and not observed at all the 266 stations, no significant temporal nor spatial trend following dam flushing operations can be 267 drawn clearly. However, OBT is heterogeneously distributed in sediments of the Rhône River 268 and large amounts of this radionuclide are still stored in the Upper Rhône sediments. Extreme events such as dam flushing operations can redistribute these storages to the downstream

270 part of the River. The radiotoxicity of free tritium (HTO) or organically bound tritium to 271 naturally occurring organic compounds (OBT) are low comparing to most other natural or 272 artificial radionuclides. Nevertheless, the specific radiotoxicity of organically bound tritium to 273 synthetic organic particles are unknown to our knowledge as well as their transfer rates 274 toward living organisms.

\section{Acknowledgements}

This study was supported by the Rhône Sediment Observatory (OSR), a multi-partner

277 research program partly funded by the Rhône Plan and by the European Regional 278 Development Fund (ERDF) allocated by the European Union. We thank the teams of OSR, 
especially those of INRAE and CEREGE, for their contribution in the field for water and sediment sampling. We are very grateful to CNR, DREAL ARA, SIG and EDF services for cooperating with OSR and sharing their monitoring data.

\section{References}

AFNOR, 2009. NF ISO 10694: Particle Size Analysis - Laser Diffraction Methods. 51 pp.

AFNOR, 1995. NF ISO 10694: Soil quality - Determination of organic and total carbon after dry combustion (elementary analysis). $7 \mathrm{pp}$.

Beaugelin-Seiller, K., Boyer, P., Garnier-Laplace, J., Adam, C., 2002. Casteaur: A simple tool to assess the transfer of radionuclides in waterways. Health Phys. 83, 539-542. https://doi.org/10.1097/00004032-200210000-00013

Bravard, J.-P., Clémens, A., 2008. Le Rhône en 100 questions. Méditerranée (report in French) $295 \mathrm{pp}$.

Bretier, M., Dabrin, A., Bessueille-Barbier, F., Coquery, M., Barbier-Bessueille, F., Coquery, M., 2019. Comparison of integrative passive sampling and discrete monitoring to assess the impact of dam flushing event on dissolved trace elements concentrations. Sci. Total Environ. 656, 433-446. https://doi.org/10.1016/j.scitotenv.2018.11.303

Brown, C.B., 1944. The control of reservoir silting. US Gov. Print. Off. 521, 168 pp.

Ciffroy, P., Siclet, F., Damois, C., Luck, M., 2006. A dynamic model for assessing radiological consequences of tritium routinely released in rivers. Application to the Loire River. J. Environ. Radioact. 90, 110-139. https://doi.org/10.1016/j.jenvrad.2006.06.012

Cossonnet, C., Neiva Marques, A.M., Gurriaran, R., 2009. Experience acquired on environmental sample combustion for organically bound tritium measurement. Appl. Radiat. Isot. 67, 809-811. https://doi.org/10.1016/j.apradiso.2009.01.039 
Currie, L.A., 1968. Limits for Qualitative Detection and Quantitative Determination: Application to Radiochemistry. Anal. Chem. 40, 586-593. https://doi.org/10.1021/ac60259a007

Ducros, L., Eyrolle, F., Vedova, C. Della, Charmasson, S., Leblanc, M., Mayer, A., Babic, M., Antonelli, C., Mourier, D., Giner, F., 2018. Tritium in river waters from French Mediterranean catchments: Background levels and variability. Sci. Total Environ. 612, 672-682. https://doi.org/10.1016/j.scitotenv.2017.08.026

Eisenbud, M., Bennett, B., Blanco, R.E., 1979. Tritium in the environment. NCRP Report No. 62. Behav. Tritium Environ.

Eyrolle-Boyer, F., Boyer, P., Claval, D., Charmasson, S., Cossonnet, C., 2014. Apparent enrichment of organically bound tritium in rivers explained by the heritage of our past. J. Environ. Radioact. 136, 162-168. https://doi.org/10.1016/j.jenvrad.2014.05.019

Eyrolle-Boyer, F., Claval, D., Cossonnet, C., Zebracki, M., Gairoard, S., Radakovitch, O., Calmon, P., Leclerc, E., 2015. Tritium and $14 \mathrm{C}$ background levels in pristine aquatic systems and their potential sources of variability. J. Environ. Radioact. 139, 24-32. https://doi.org/10.1016/j.jenvrad.2014.09.015

Eyrolle, F., Lepage, H., Copard, Y., Ducros, L., Claval, D., Saey, L., Cossonnet, C., Giner, F., Mourier, D., 2018. A brief history of the origins and contents of Organically Bound Tritium (OBT) and $14 \mathrm{C}$ in the sediments of the Rhône watershed. Sci. Total Environ. in review, 40-51. https://doi.org/10.1016/j.scitotenv.2018.06.074

Fruchard, F., Camenen, B., 2012. Reservoir sedimentation: different type of flushing-friendly flushing example of genissiat dam flushing. ICOLD Int. Symp. Dams a Chang. world $6 \mathrm{pp}$. IRSN, 2015. Bilan de l'état radiologique de l'environnement français de juin 2011 à décembre 2014. PRP-ENV (french report) 253p. 
IRSN, 2013. Constat radiologique Vallée du Rhône. Rapport final relatif au milieu aquatique. PRP-ENV/SESURE (french report) 37, 68p.

Jean-Baptiste, P., Baumier, D., Fourré, E., Dapoigny, A., Clavel, B., 2007. The distribution of tritium in the terrestrial and aquatic environments of the Creys-Malville nuclear power plant (2002-2005). J. Environ. Radioact. 94, 107-118. https://doi.org/10.1016/j.jenvrad.2007.01.010

Jean-Baptiste, P., Fontugne, M., Fourré, E., Marang, L., Antonelli, C., Charmasson, S., Siclet, F., 2018. Tritium and radiocarbon levels in the Rhône river delta and along the French Mediterranean coastline. J. Environ. Radioact. 187, 53-64. https://doi.org/10.1016/j.jenvrad.2018.01.031

Kalnejais, L.H., Martin, W.R., Bothner, M.H., 2010. The release of dissolved nutrients and metals from coastal sediments due to resuspension. Mar. Chem. 121, 224-235. https://doi.org/10.1016/j.marchem.2010.05.002

Kim, S.B., Baglan, N., Davis, P.A., 2013. Current understanding of organically bound tritium (OBT) in the environment. J. Environ. Radioact. 126, 83-91. https://doi.org/10.1016/j.jenvrad.2013.07.011

Krejci, K., Zeller, J., 1979. Tritium pollution in the Swiss luminous compound industry, in: International Symposium on the Behaviour of Tritium in the Environment. IAEA, Vienna, pp. 65-77.

Launay, M., 2014. Flux de matières en suspension, de mercure et de PCB particulaires dans le Rhône, du Léman à la Méditerranée. Thesis (in French) 434. https://doi.org/10.1002/oby.20222

Lepage, H., Launay, M., Le Coz, J., Angot, H., Miège, C., Gairoard, S., Radakovitch, O., Coquery, M., 2020. Impact of dam flushing operations on sediment dynamics and quality in the 
upper Rhône River, France. J. Environ. Manage. 255, 109886. https://doi.org/10.1016/j.jenvman.2019.109886

352

Masson, M., Angot, H., Le Bescond, C., Launay, M., Dabrin, A., Miège, C., Le Coz, J., Coquery, M., 2018. Sampling of suspended particulate matter using particle traps in the Rhône River: Relevance and representativeness for the monitoring of contaminants. Sci. Total Environ. 637-638, 538-549. https://doi.org/10.1016/j.scitotenv.2018.04.343

Monnin, L., Ciffroy, P., Garnier, J.M., Ambrosi, J.P., Radakovitch, O., 2018. Remobilization of trace metals during laboratory resuspension of contaminated sediments from a dam reservoir. J. Soils Sediments 18, 2596-2613. https://doi.org/10.1007/s11368-018-19315

Morereau, A., Lepage, H., Claval, D., Cossonnet, C., Radakovitch, O., Ambrosi, J.-P., Mourier, B., Eyrolle, F., n.d. Technogenic tritium contamination from watchmaking industry and its resiliency in river sediments of the Rhône River (France).

OFSP, 2015. Radenviro.ch [WWW Document]. URL http://www.radenviro.ch/fr$\mathrm{CH} /$ measures/274 (accessed 7.5.16).

Peter, D.H., Castella, E., Slaveykova, V.I., 2014. Effects of a reservoir flushing on trace metal partitioning, speciation and benthic invertebrates in the floodplain. Environ. Sci. Process. Impacts 16, 2692-2702. https://doi.org/10.1039/c4em00387j

Peteuil, C., Fruchart, F., Abadie, F., Reynaud, S., Camenen, B., Guertault, L., 2013. Sustainable management of sediment fluxes in reservoir by environmental friendly flushing : the case study of the Genissiat dam on the upper Rhone River (France), in: 12th International Conference on River Sedimentation. Kyoto (Japan), pp. 1147-1156.

Poulier, G., Launay, M., Le Bescond, C., Thollet, F., Coquery, M., 2019. Combining flux monitoring and estimation to establish annual budgets of suspended particulate matter 
and associated pollutants in the Rhône River from Lake Geneva to the Mediterranean Sea. Sci. Total Environ. 658, 457-473. https://doi.org/10.1016/J.SCITOTENV.2018.12.075

Provansal, M., Dufour, S., Sabatier, F., Anthony, E.J., Raccasi, G., Robresco, S., 2014. The geomorphic evolution and sediment balance of the lower Rhône River (southern France) over the last 130years: Hydropower dams versus other control factors. Geomorphology 219, 27-41. https://doi.org/10.1016/j.geomorph.2014.04.033

Schulze, T., Ricking, M., Schröter-Kermani, C., Körner, A., Denner, H.-D., Weinfurtner, K., Winkler, A., Pekdeger, A., 2007. The German Environmental Specimen Bank - Sampling, processing, and archiving sediment and suspended particulate matter. J. Soils Sediments 7, 361-367. https://doi.org/10.1065/jss2007.08.248

Schürch, M., Kozel, R., Schotterer, U., Tripet, J.-P.P., Sch??rch, M., Kozel, R., Schotterer, U., Tripet, J.-P.P., 2003. Observation of isotopes in the water cycle-the Swiss National Network (NISOT). Environ. Geol. 45, 1-11. https://doi.org/10.1007/s00254-003-0843-9

Syvitski, J.P.M., Vörösmarty, C.J., Kettner, A.J., Green, P., 2005. Impact of humans on the flux of terrestrial sediment to the global coastal ocean. Science (80-. ). 308, 376-380. https://doi.org/10.1126/science.1109454

Thollet, F., Le Bescond, C., Lagouy, M., Gruat, A., Grisot, G., Le Coz, J., Coquery, M., Lepage, H., Gairoard, S., Gattacceca, J.C., Ambrosi, J.-P., Radakovitch, O., 2018. Observatoire des sédiments du Rhône. https://doi.org/10.17180/OBS.OSR

Ueda, S., Hasegawa, H., Kakiuchi, H., Ochiai, S., Akata, N., Hisamatsu, S., 2015. Nuclear accident-derived ${ }^{3} \mathrm{H}$ in river water of Fukushima Prefecture during 2011-2014. J. Environ. Radioact. 146, 102-109. https://doi.org/10.1016/j.jenvrad.2015.04.014 
Figure 1 - Location of the studied dams, the nuclear power plant and the sampling stations in the Rhône River.

Figure 2 - Concentration of tritium in filtered waters $\left(\mathrm{HTO}^{\text {in }} \mathrm{Bq} \mathrm{L}^{-1}\right)$ measured at the four stations during the flushing operations of Génissiat, Chancy-Pougny and Verbois dams and range of the concentrations observed on the water of the Rhône River in 2012 (IRSN, 2013). * samples with HTO concentration below the detection limit.

Figure 3 - Concentration of organically bound tritium (OBT in $\mathrm{Bq}^{-1}{ }_{\mathrm{cw}}$ ) measured in SPM collected at the four stations during the flushing operations of Génissiat, Chancy-Pougny and Verbois dams and range of the concentrations observed on sediment and SPM of the Rhône River in 2012 (Eyrolle et al., (2018)). 


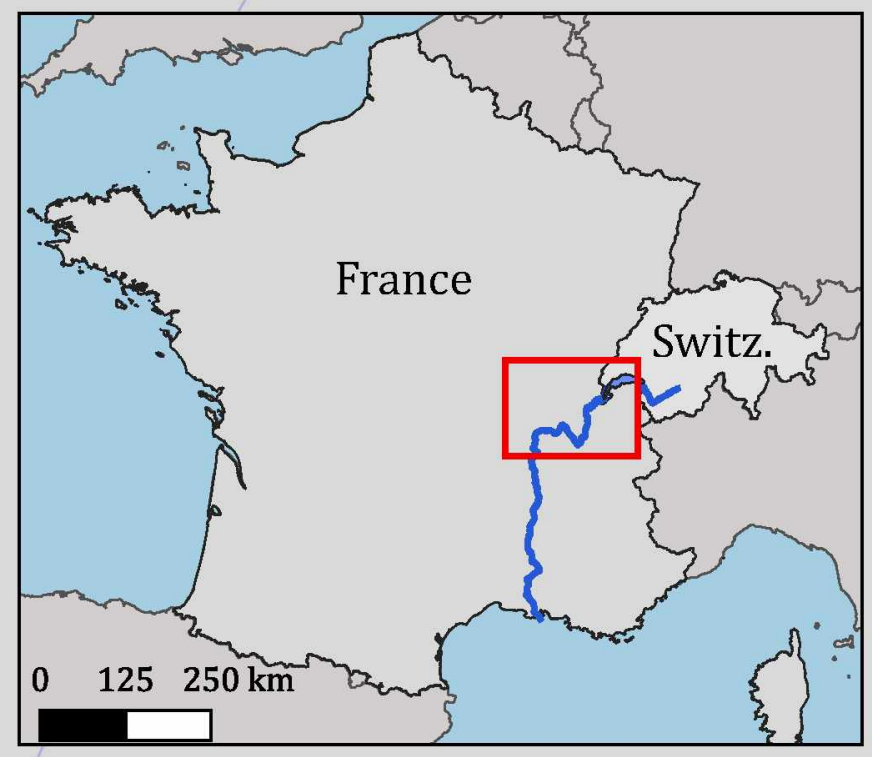


HTO concentration (Bq. $\mathrm{L}^{-1}$ )

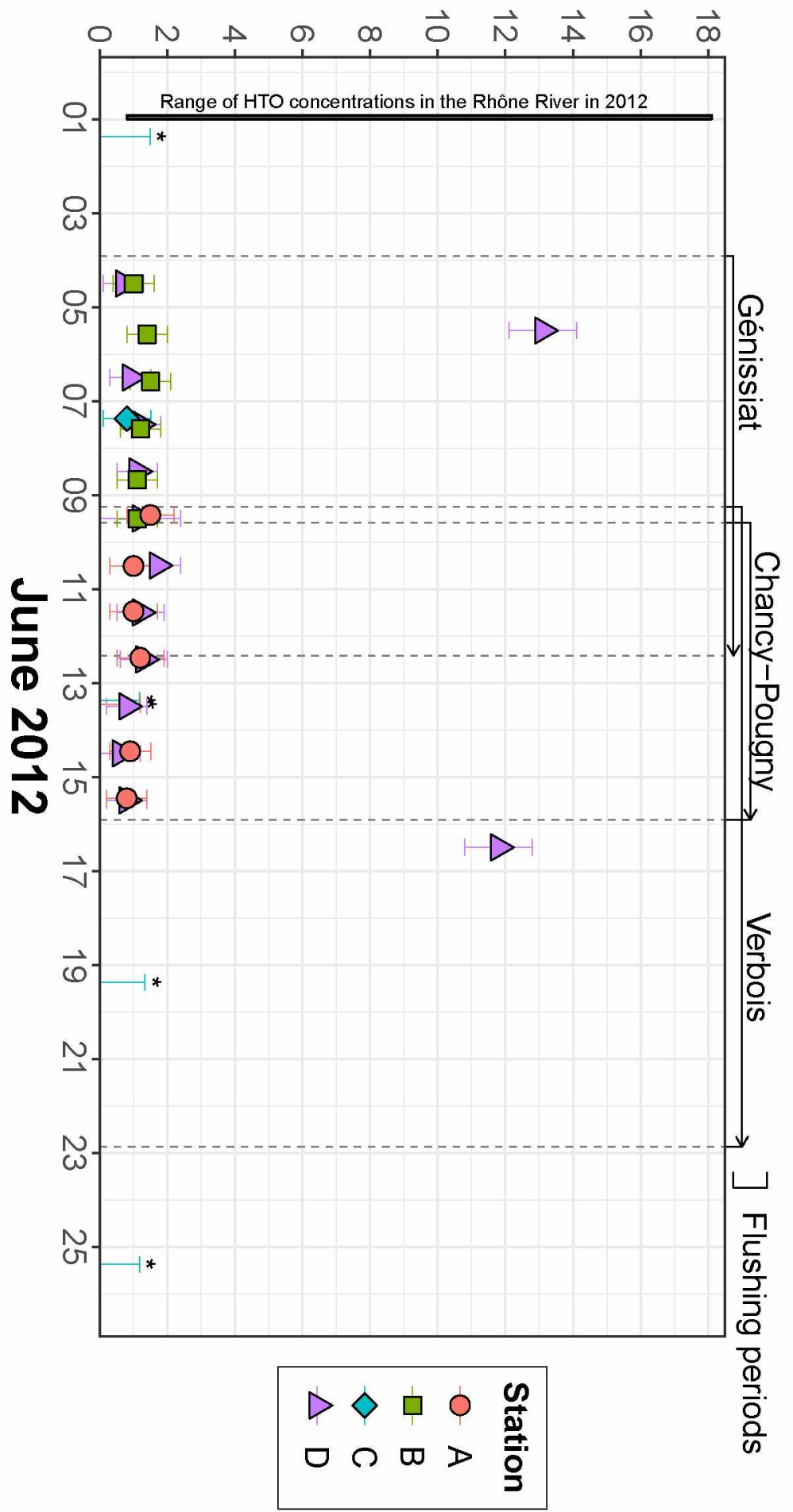




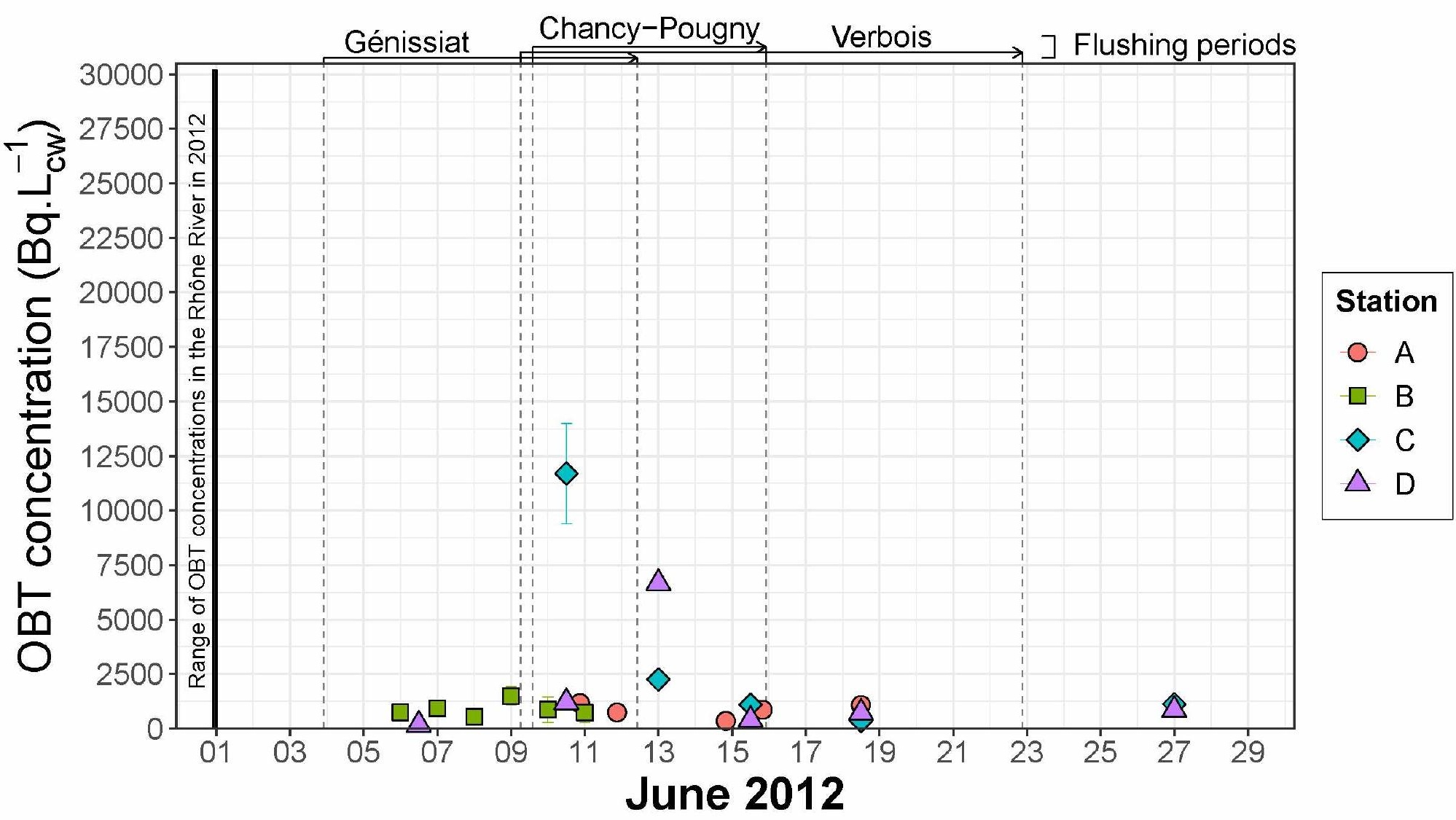


Table 1 - Number $(n)$ of samples collected during the studied flushing operations for tritiated water (HTO) and organically bound tritium (OBT) and associated sampling method used. AWS = automatic water sampler, PT = particle trap.

\begin{tabular}{|c|c|c|c|c|}
\hline Location & $\begin{array}{c}\text { Latitude } \\
\text { (WGS 1984) }\end{array}$ & $\begin{array}{c}\text { Longitude } \\
\text { (WGS 1984) }\end{array}$ & HTO & OBT \\
\hline A & +46.1442 & +5.9644 & Manual $(n=7)$ & PT $(n=5)$ \\
\hline B & +45.9642 & +5.8310 & Manual $(n=6)$ & PT $(n=6)$ \\
\hline C & +45.80 & +5.4322 & AWS $(n=6)$ & PT $(n=5)$ \\
\hline D & +5.0896 & +45.8121 & Manual $(n=13)$ & PT $(n=6)$ \\
\hline
\end{tabular}




\section{Declaration of interests}

$\square$ The authors declare that they have no known competing financial interests or personal relationships that could have appeared to influence the work reported in this paper.

$\square$ The authors declare the following financial interests/personal relationships which may be considered as potential competing interests: 
Electronic supplementary materials

Figure ESM1 - Discharge and suspended particulate matters (SPM) concentration measured at the four stations during the flushing operations (Thollet et al., 2018).

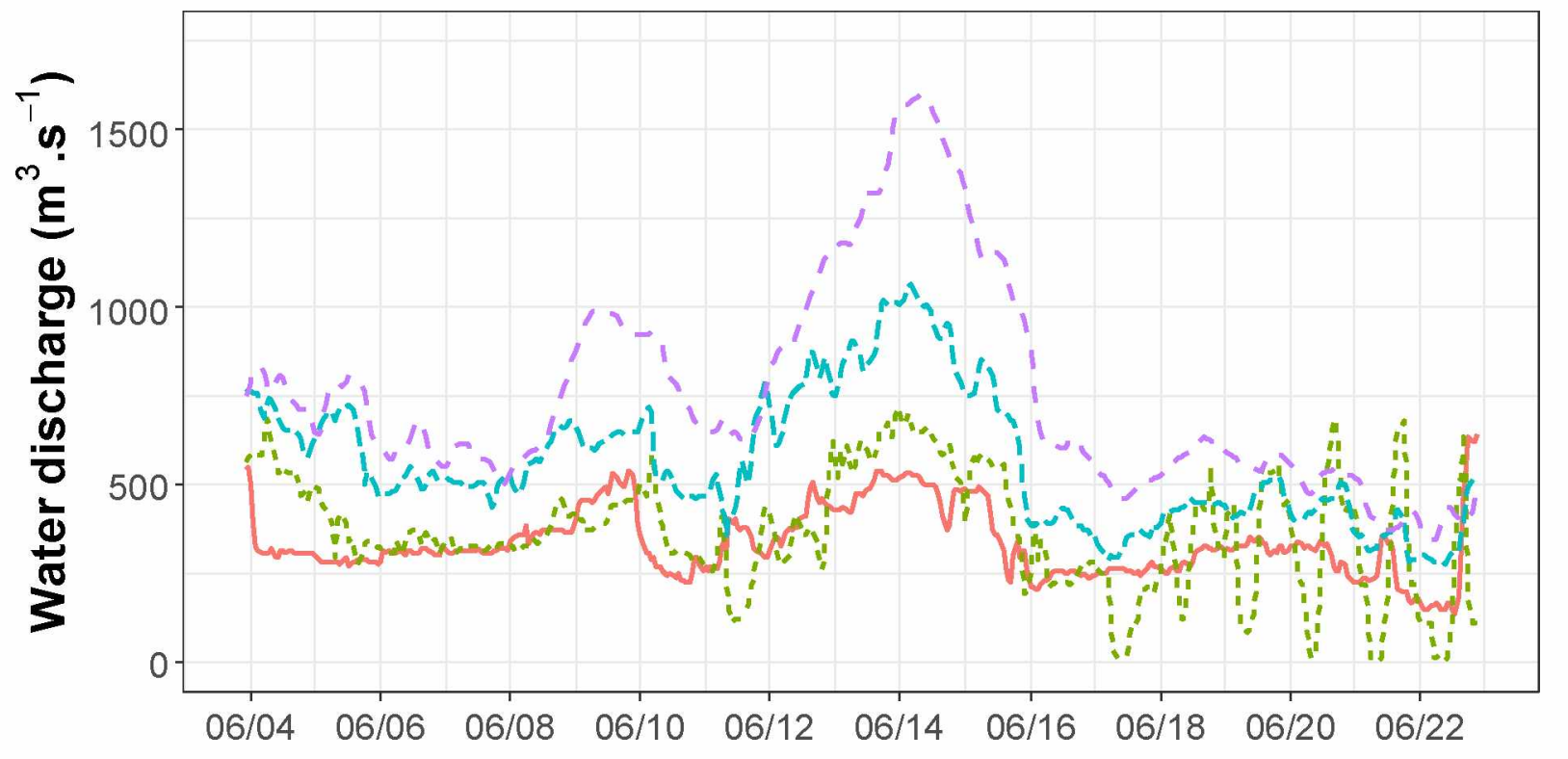

Station

$-A$
$=-B$
$=-C$
$==D$

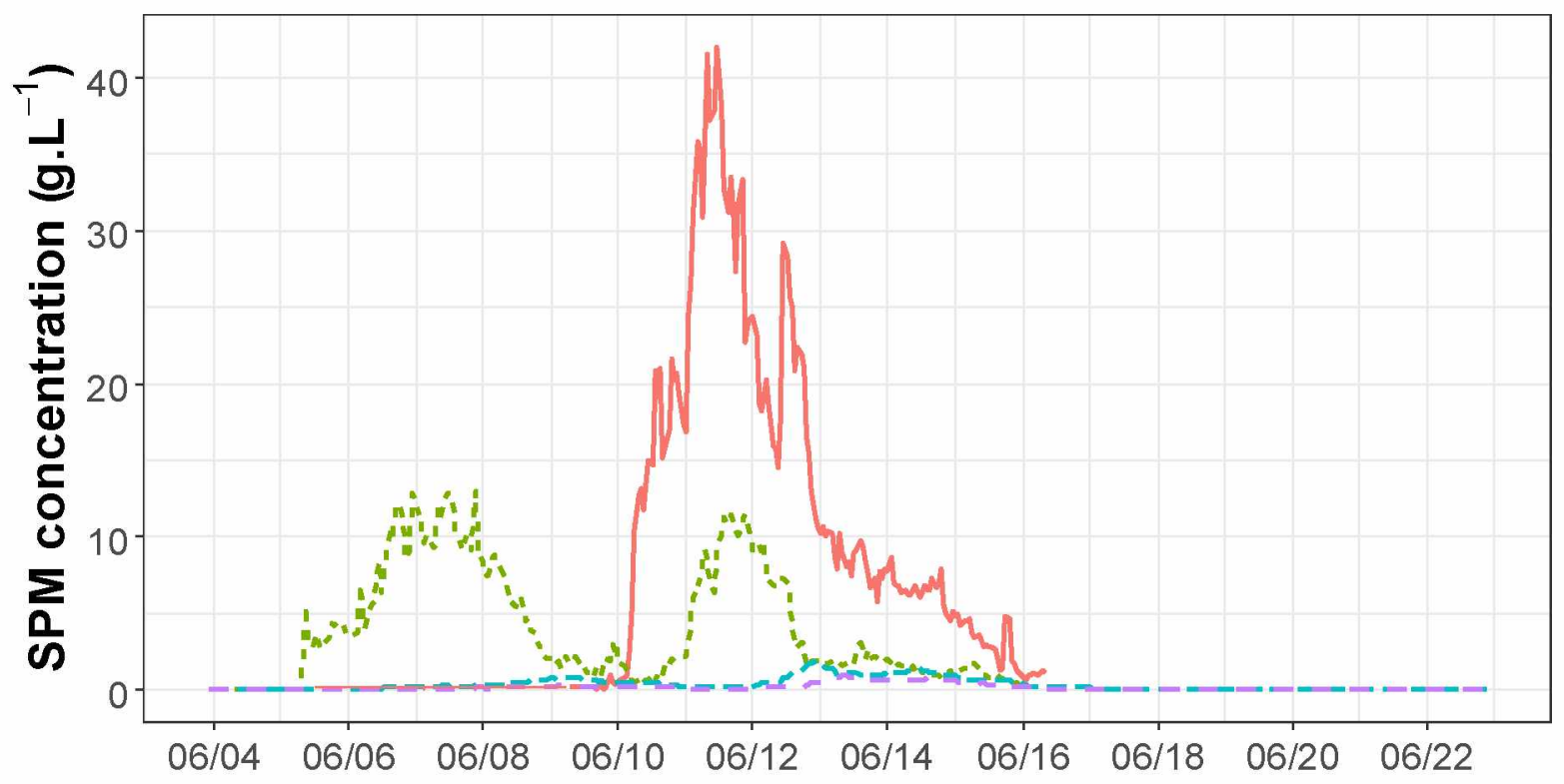

Station

- A

$==B$

$--\mathrm{C}$

$-=\mathrm{D}$ 
Table ESM1 - Tritiated water concentration in the water samples collected for this study. "<" indicate concentration under the detection limit.

\begin{tabular}{|c|c|c|}
\hline Station & Sampling date & Concentration $\left(\mathrm{Bq} \mathrm{L}^{-1}\right)$ \\
\hline A & $06 / 09 / 201210: 20$ & $1.5 \pm 0.7$ \\
\hline A & $06 / 10 / 201212: 20$ & $1.0 \pm 0.7$ \\
\hline A & $06 / 11 / 201211: 30$ & $1.0 \pm 0.7$ \\
\hline A & $06 / 12 / 201211: 15$ & $1.2 \pm 0.7$ \\
\hline A & $06 / 13 / 201210: 55$ & $<1.2$ \\
\hline $\mathrm{A}$ & $06 / 14 / 201211: 00$ & $0.9 \pm 0.6$ \\
\hline $\mathrm{A}$ & $06 / 15 / 201211: 00$ & $0.8 \pm 0.6$ \\
\hline B & 06/04/2012 12:05 & $1.0 \pm 0.6$ \\
\hline $\mathrm{B}$ & $06 / 05 / 201214: 00$ & $1.4 \pm 0.6$ \\
\hline $\mathrm{B}$ & $06 / 06 / 201214: 00$ & $1.5 \pm 0.6$ \\
\hline B & 06/07/2012 14:15 & $1.2 \pm 0.6$ \\
\hline $\mathrm{B}$ & $06 / 08 / 201216: 15$ & $1.1 \pm 0.6$ \\
\hline B & 06/09/2012 12:15 & $1.1 \pm 0.6$ \\
\hline $\mathrm{C}$ & 05/25/2012 09:00 & $<1.4$ \\
\hline $\mathrm{C}$ & 06/01/2012 09:00 & $<1.5$ \\
\hline $\mathrm{C}$ & 06/07/2012 09:00 & $0.8 \pm 0.7$ \\
\hline $\mathrm{C}$ & 06/13/2012 09:00 & $<1.2$ \\
\hline C & 06/19/2012 09:00 & $<1.3$ \\
\hline C & $06 / 25 / 201209: 00$ & $<1.2$ \\
\hline $\mathrm{D}$ & 06/04/2012 12:00 & $0.7 \pm 0.6$ \\
\hline D & $06 / 05 / 2012$ 12:00 & $13.1 \pm 1.0$ \\
\hline $\mathrm{D}$ & $06 / 06 / 201212: 00$ & $0.9 \pm 0.6$ \\
\hline $\mathrm{D}$ & $06 / 07 / 201212: 00$ & $1.2 \pm 0.6$ \\
\hline $\mathrm{D}$ & $06 / 08 / 201212: 00$ & $1.1 \pm 0.6$ \\
\hline $\mathrm{D}$ & $06 / 09 / 201212: 00$ & $1.2 \pm 1.2$ \\
\hline $\mathrm{D}$ & $06 / 10 / 201212: 00$ & $1.7 \pm 0.7$ \\
\hline $\mathrm{D}$ & $06 / 11 / 201212: 00$ & $1.2 \pm 0.7$ \\
\hline $\mathrm{D}$ & $06 / 12 / 201212: 00$ & $1.3 \pm 0.7$ \\
\hline $\mathrm{D}$ & $06 / 13 / 201212: 00$ & $0.8 \pm 0.6$ \\
\hline $\mathrm{D}$ & $06 / 14 / 201212: 00$ & $0.6 \pm 0.6$ \\
\hline D & $06 / 15 / 2012$ 12:00 & $0.8 \pm 0.6$ \\
\hline $\mathrm{D}$ & 06/16/2012 12:00 & $11.8 \pm 1.0$ \\
\hline
\end{tabular}

Table ESM2 - Organically bound tritium concentrations, clay/silt/sand content and POC concentrations in the suspended particulate matters (SPM) samples collected by particles trap for this study. n.a.: not analyzed; \pm analytical uncertainty.

\begin{tabular}{|c|c|c|c|c|c|c|c|c|}
\hline Station & Sampling start & Sampling end & $\begin{array}{c}\text { Concentration } \\
\left(\mathrm{Bq} \mathrm{kg}^{-1}\right)\end{array}$ & $\begin{array}{c}\text { Concentration } \\
\left(\mathrm{Bq} \mathrm{L}^{-1} \mathrm{cw}\right)\end{array}$ & $\begin{array}{c}\text { Clay } \\
(\%)\end{array}$ & $\begin{array}{c}\text { Silt } \\
(\%)\end{array}$ & $\begin{array}{c}\text { Sand } \\
(\%)\end{array}$ & $\begin{array}{c}\text { POC } \\
\left(\mathrm{mg}^{\mathrm{kg}}{ }^{-1}\right)\end{array}$ \\
\hline A & $06 / 10 / 201211: 00$ & $06 / 11 / 201207: 00$ & $16 \pm 8$ & $1180 \pm 400$ & 3.4 & 72.8 & 23.8 & $9.2 \pm 0.5$ \\
\hline A & $06 / 11 / 201211: 15$ & $06 / 12 / 201207: 00$ & $7 \pm 1$ & $750 \pm 40$ & 2.5 & 50.4 & 47.1 & $9.8 \pm 0.5$ \\
\hline A & $06 / 14 / 201208: 00$ & $06 / 15 / 201208: 00$ & $5 \pm 1$ & $360 \pm 20$ & 2.0 & 41.1 & 56.8 & $9.6 \pm 0.5$ \\
\hline A & $06 / 15 / 201208: 00$ & $06 / 16 / 201208: 00$ & $8 \pm 1$ & $870 \pm 40$ & n.a & n.a & n.a & n.a \\
\hline A & $06 / 16 / 201212: 00$ & $06 / 20 / 201211: 59$ & $15 \pm 1$ & $1090 \pm 60$ & n.a & n.a & n.a & n.a \\
\hline B & $06 / 05 / 201212: 00$ & $06 / 06 / 201211: 59$ & $17 \pm 1$ & $750 \pm 160$ & 2.2 & 59.9 & 37.9 & $22.8 \pm 0.9$ \\
\hline B & $06 / 06 / 201212: 00$ & $06 / 07 / 201211: 59$ & $12 \pm 1$ & $940 \pm 330$ & 2.0 & 53.1 & 44.9 & $18.8 \pm 0.8$ \\
\hline B & $06 / 07 / 201212: 00$ & $06 / 08 / 201211: 59$ & $6 \pm 1$ & $540 \pm 220$ & 2.8 & 68.0 & 29.3 & $15.3 \pm 0.7$ \\
\hline B & $06 / 08 / 201212: 00$ & $06 / 09 / 201211: 59$ & $24 \pm 2$ & $1500 \pm 420$ & 1.5 & 35.8 & 62.7 & $6.8 \pm 0.4$ \\
\hline B & $06 / 09 / 201212: 00$ & $06 / 10 / 201211: 59$ & $6 \pm 1$ & $870 \pm 580$ & 1.6 & 42.7 & 55.7 & $12.1 \pm 0.6$ \\
\hline B & $06 / 10 / 201212: 00$ & $06 / 11 / 201211: 59$ & $5 \pm 1$ & $730 \pm 460$ & 1.9 & 47.3 & 50.8 & $11.9 \pm 0.6$ \\
\hline C & $06 / 09 / 201212: 00$ & $06 / 11 / 201211: 59$ & $279 \pm 14$ & $11700 \pm 2300$ & 7.1 & 92.7 & 0.2 & $15.3 \pm 0.7$ \\
\hline C & $06 / 11 / 201212: 00$ & $06 / 14 / 201211: 59$ & $51 \pm 3$ & $2250 \pm 120$ & 4.4 & 94.2 & 1.3 & $11.8 \pm 0.5$ \\
\hline C & $06 / 14 / 201212: 00$ & $06 / 16 / 201211: 59$ & $23 \pm 1$ & $1100 \pm 60$ & 5.2 & 93.2 & 1.7 & $11.3 \pm 0.5$ \\
\hline C & $06 / 16 / 201212: 00$ & $06 / 20 / 201211: 59$ & $8 \pm 1$ & $340 \pm 20$ & 4.7 & 87.9 & 7.4 & n.a \\
\hline C & $06 / 20 / 201212: 00$ & $07 / 03 / 201211: 59$ & $21 \pm 2$ & $1130 \pm 60$ & n.a & n.a & n.a & n.a \\
\hline
\end{tabular}




\begin{tabular}{|c|c|c|c|c|c|c|c|c|}
\hline D & $06 / 05 / 201212: 00$ & $06 / 07 / 201211: 59$ & $4 \pm 1$ & $180 \pm 40$ & 4.8 & 83.9 & 11.4 & $15.8 \pm 0.7$ \\
\hline D & $06 / 09 / 201212: 00$ & $06 / 11 / 201211: 59$ & $32 \pm 2$ & $1210 \pm 210$ & 4.7 & 93.2 & 2.1 & $17.1 \pm 0.8$ \\
\hline D & $06 / 11 / 201212: 00$ & $06 / 14 / 201211: 59$ & $174 \pm 9$ & $6670 \pm 340$ & 3.2 & 54.6 & 42.2 & $8.1 \pm 0.5$ \\
\hline D & $06 / 14 / 201212: 00$ & $06 / 16 / 201211: 59$ & $5 \pm 1$ & $400 \pm 20$ & 3.6 & 93.0 & 3.5 & $12.1 \pm 0.6$ \\
\hline D & $06 / 16 / 201212: 00$ & $06 / 20 / 201211: 59$ & $10 \pm 1$ & $730 \pm 40$ & 5.6 & 92.5 & 1.9 & n.a \\
\hline D & $06 / 20 / 201212: 00$ & $07 / 03 / 201211: 59$ & $20 \pm 1$ & $860 \pm 40$ & 4.9 & 93.0 & 2.0 & $36.0 \pm 1.8$ \\
\hline
\end{tabular}

